\title{
Climate Change Impact Assessment on Outdoor Thermal Comfort Changes Using Physiological Equivalent Temperature (PET) Index in Mashhad
}

\section{ART ICLE INF O}

\section{Article Type}

Original Research

\section{Authors}

Sanagar Darbani E. ${ }^{1} M A$,

Rafieian M. ${ }^{2} P h D$,

Hanaee T. $P h D$,

Monsefi Parapari D. ${ }^{3} P h D$

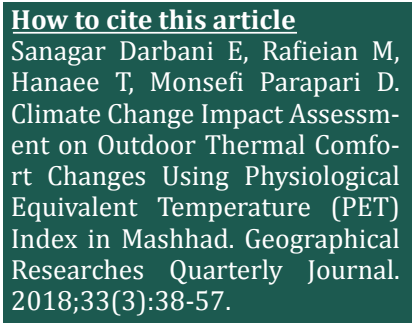

*Department of Urbanism, Mashhad Branch, Islamic Azad University, Mashhad, Iran

${ }^{1}$ Department of Urbanism, Mashhad Branch, Islamic Azad University, Mashhad, Iran

${ }^{2}$ Department of Urbanism, Faculty of Arts, Tarbiat Modares University, Tehran, Iran

${ }^{3}$ Department of Architecture, Faculty of Architecture \& Urbanism, Shahrood University Technology, Shahrood, Iran

\section{*Correspondence}

Address: Floor 1, NO. 19, Golestan Alley, Hashemieh 91.1, mashhad, Iran. Postal Code: 9178146713

Phone: -

Fax: -

Toktamhanaee@yahoo.com

\section{Article History}

Received: April 14, 2018

Accepted: August 21, 2018

ePublished: December 09, 2018

\section{A B S T R A C T}

Introduction and Background In recent decades, increasing earth heat lead to the death of thosands of people in the world. This situation cause urban planning meet a major climate change challenges which needs to mitigate its effects. Increasing in population and various related activities in different fields has led to problems such as wave heat throughout the world. In addition, changing the pattern of these changes and their unpredictability has increased in cities, thus concern about reducing and adapting to these hazards in different dimensions lead to pay more attention to urban life and promoting human health.

Aims The aim of this paper is to investigate effect of climate change which is caused by heat wave on outdoor thermal comfort in Mashhad city.

Methodology Data collection method was based on library studies and also data gathered from meteorological station of Mashhad in the period of 10 years (2017-2007). The analysis method was based on Rayman and Excell software in Mashhad and physiological equivalent temperature (PET) index was the most commonly used index for evaluating outdoor thermal comfort.

Conclusion Findings show that climate change and the effects of heat wave in Mashhad in July and August have affected the outdoor thermal comfort, which put human health at more risk in these months. Moreover, studies of outdoor thermal comfort changes in winter in this city shows that warming of these seasons experienced a rapid pace, so that over the past 10 years, outdoor thermal comfort has increased by $+1.4^{\circ} \mathrm{C}$ in March, this number will reach $1.1+$ in summer and July. Studies show that the summer and spring seasons of Mashhad are entering to the thermal stress range, while its cold seasons are becoming warmer and entering to outdoor thermal comfort range.

Keywords Climate Change; Outdoor Thermal Comfort; physiological equivalent temperature(PET); Mashhad

\section{I T A T I O N L I N K S}

[Akbari \& Konopacki; 2004] Energy effects of heat-island ...; [Ali-Toudert; 2005] Dependence of outdoor thermal comfort ...; [Analitis, et al.; 2008] Effects of cold weather on mortality ...; [ASHRAE; 2009] Fundamentals, American society of ...; [ASHRAE; 2004] Fundamentals, American society of ...; [Cheung \& Hart; 2014] Climate change and thermal comfort ...; [Cimellaro; 2016] Urban resilience for emergency ...; [Dai; 2014] The impact of urban form on thermal ...; [Djongyang, et al; 2010] Thermal comfort ...; [Draper \& Richards; 2009] Dictionary for managing trees in ...; [Ebrahimzadeh \& Esmaeil Negad; 2017] The future challenge of climatic refugees regional ...; [Erell, et al; 2010] Urban microclimate: Designing the ...; [Fallah Ghalhari, et al; 2016] Assessing the seasonal variability of thermal ...; [Fanger; 1970] Thermal comfort: Analysis and applications ...; [Hajat, et al.; 2006] Impact of high temperatures on mortality ...; [Hansen et al.; 2008] The effect of heat waves on mental ...; [Heidari \& Monam; 2013] Evaluation of thermal comfort indices in ...; [Hensel; 1981] Thermoreception and Temperature ...; [Höppe; 2002] Different aspects of assessing indoor ...; [IPCC; 2007] Climate change synthesis report summary ...; [Johansson; 2006] Influence of urban geometry on outdoor ...; [Karimian; 2013] Optimization of urban green space for the ...; [Linares \& Díaz; 2008] Impact of high temperatures on hospital ...; [Matzarakis, et al.; 2002] Radiation and thermal ...; [Matzarakis, et al.; 2010] Modelling radiation fluxes in simple ...; [Monsefi Parapari; 2015] Adaptation to climate change ...; [Morris; 2008] History of urban form ...; [Oliver; 2005] Encyclopedia of world ...; [Pirard et al.; 2005] Summary of the mortality...; [Prasad et al.; 2009] Climate resilient cities ...; [Qanbarzadeh \& Behniafar; 2007] Fundemental of environmental ...; [Roaf, et al.; 2009] Adapting buildings and cities for ...; [Shams, et al.; 2014] Assessing climate conditions of Mashhad ...; [Szokolay; 2008] Architectural science the ...; [Taylor et al.; 2015] Mapping the effects of urban heat island ...; [Wilkinson; 2001] Cold comfort: The social and environmental ...; [Yang, Qet al.; 2016] Research on urban heat-island ...; [Yilmaz, et al.; 2013] The importance of thermal comfort in ...; [Yow; 2007] Urban heat Islands: Observations ...; [Zolfaghari; 2008] Determination of suitable calendar ... 
Sanagar Darbani E. MA

Rafieian M. PhD

Hanaee T. PhD

Monsefi Parapari D. PhD

Toktamhanaee@yahoo.com

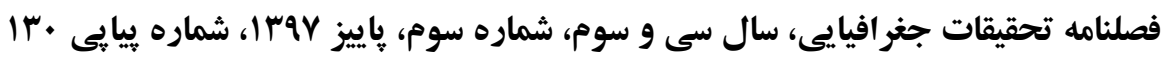

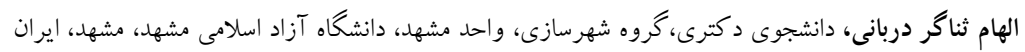

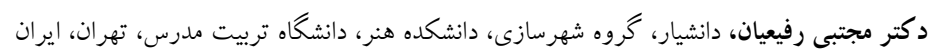

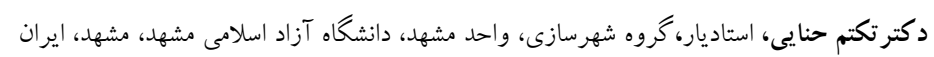

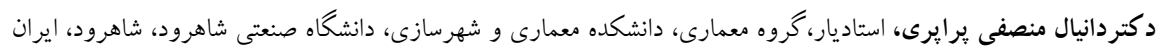

\title{
ارزيابى اثرات تغييرات اقليمى بر تغييرات آسايش حرارتى بيرونى با استفاده از شاخص دماى معادل فيزيولوزيكى (PET) در شهر مشهد
}

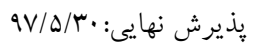

دريافت مقاله:

\section{جكيده}

مقدمه: در دهههاى اخير گرمايش زمين سبب مرگ هزاران نفر در جهان شده است. اين امر سبب گرديده تا برنامهريزى

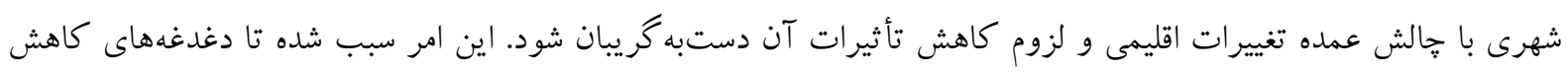

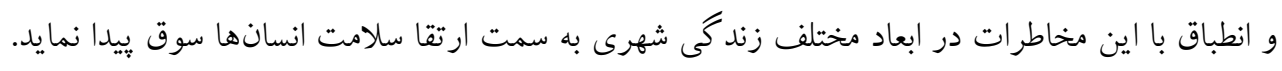
اهداف: تحقيق حاضر باهدف بررسى تأثيرات تغييرات اقليمى ناشى از موج گرما برآسايش حرارتى بيرونى در شهر مشهد است.

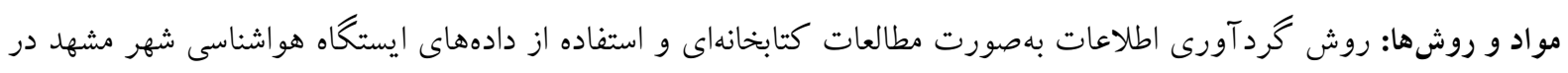

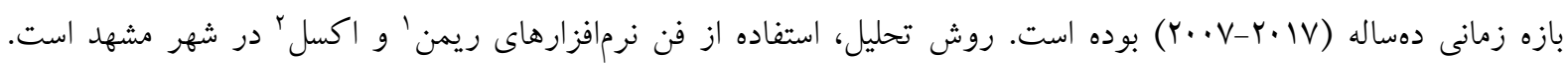

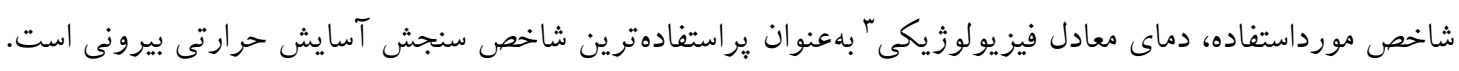

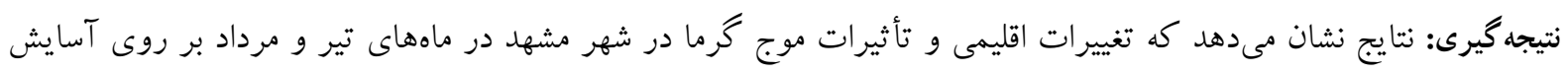

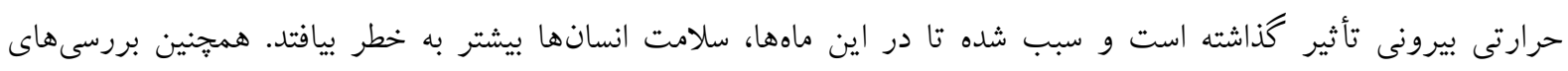

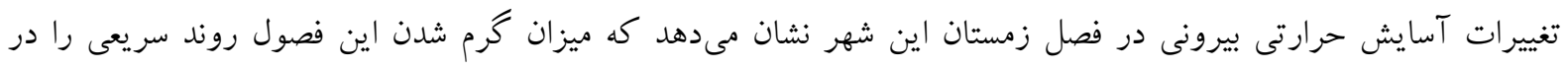

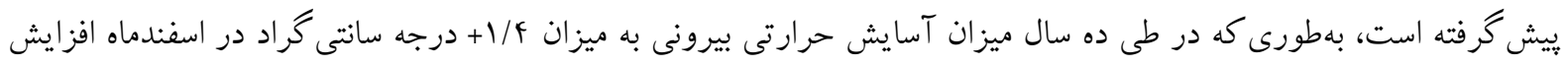

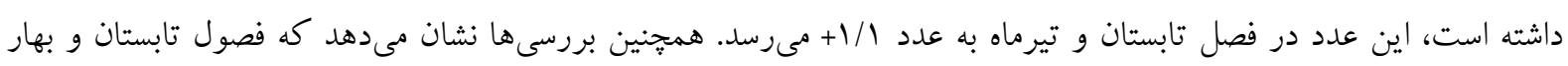

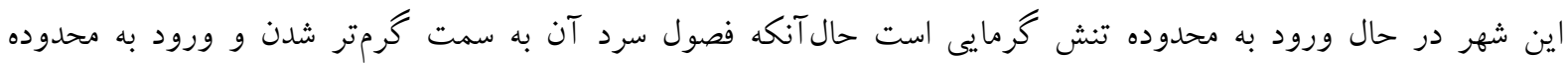
آسايش حرارتى بيرونى است. وازگ كان كليدى: تغييرات اقليمى، آسايش حرارتى بيرونى، دماى معادل فيزيولوزيكى (PET)، مشهد 


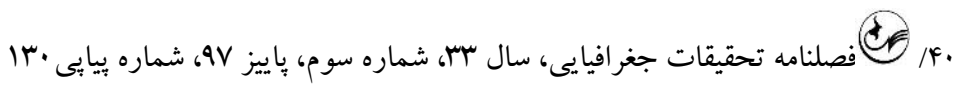

مقدمه

مشاهدات متعدد و مدلسازىهاى مختلف تائيد مى كند كه اقليم زمين نسبت به كذشته، گرمتر شده است. اين امر بهنوبه خود

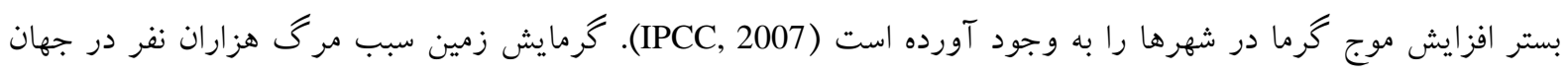

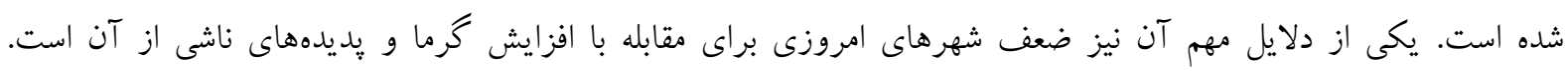

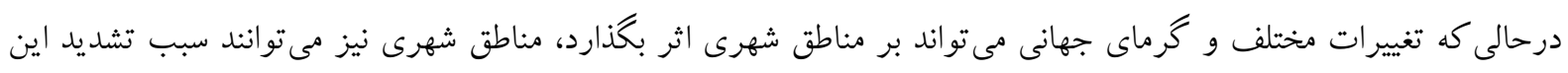

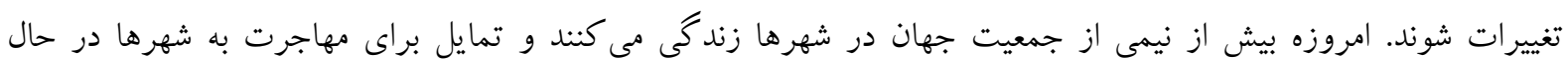

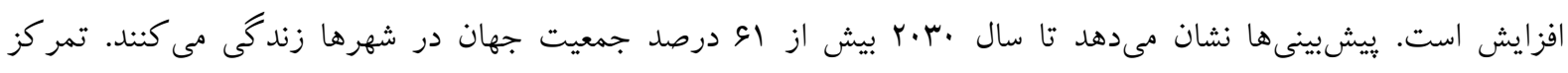

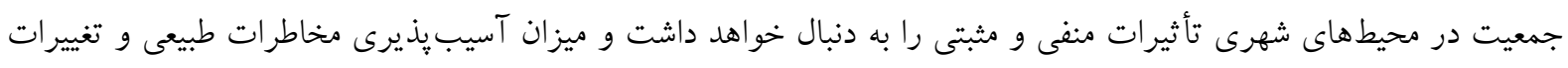

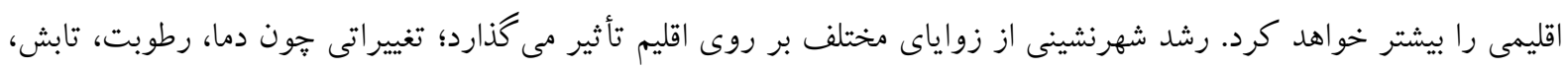

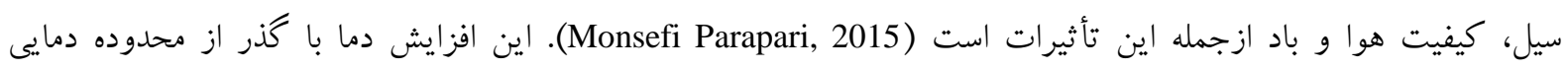

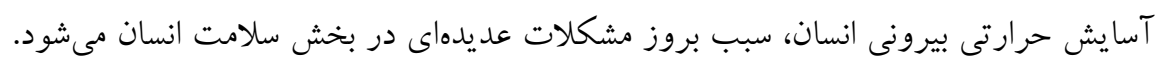

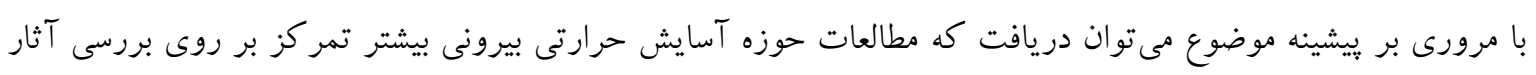

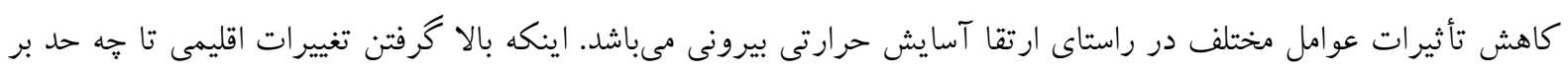

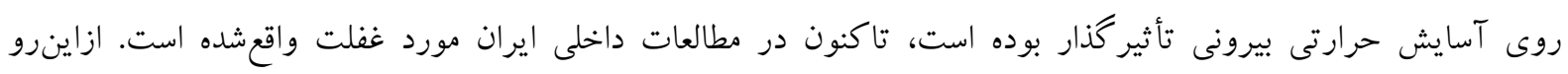

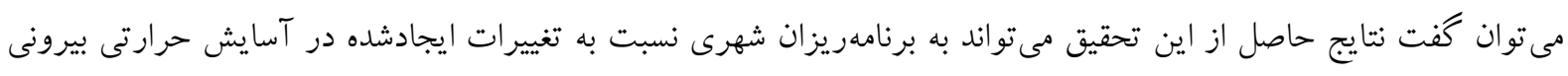

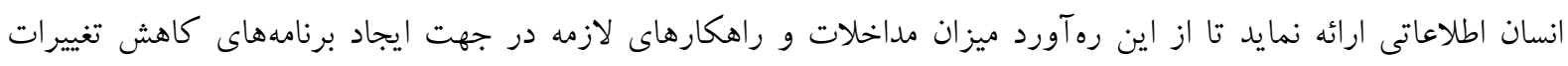
اقليمى ايجاد شود. اين برنامها در لايههاى مختلف شهرى بايستى مورد تأكيد قرار كيرد.

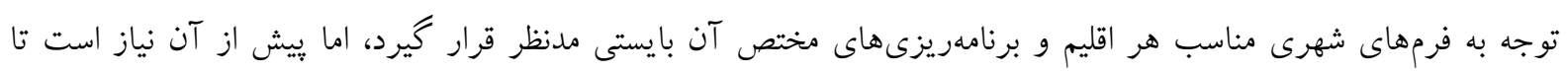

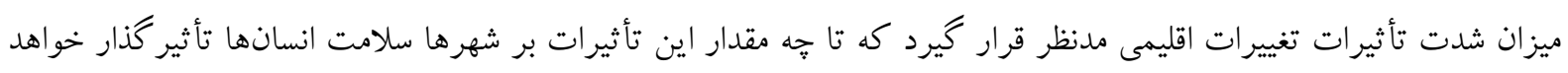

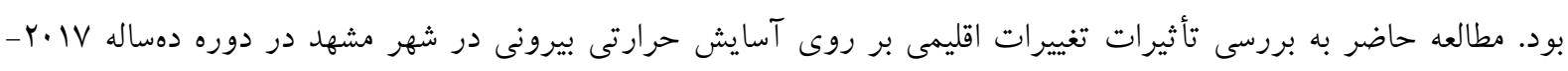

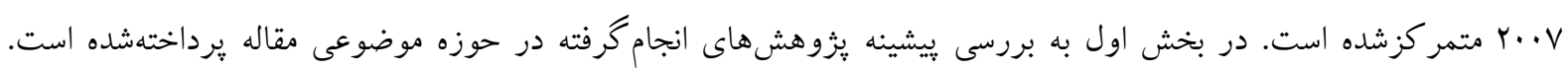

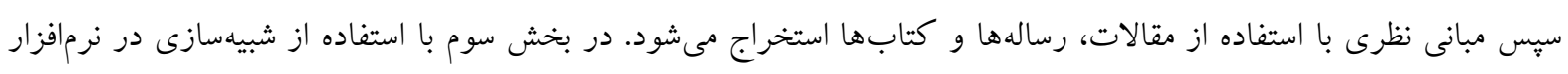

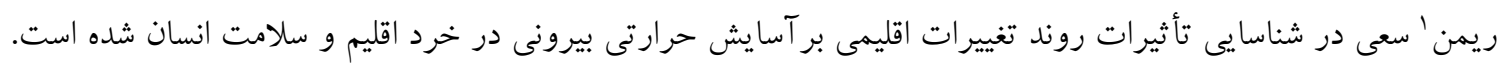

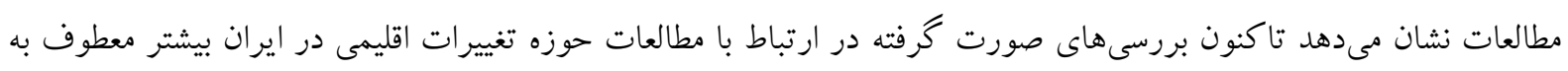

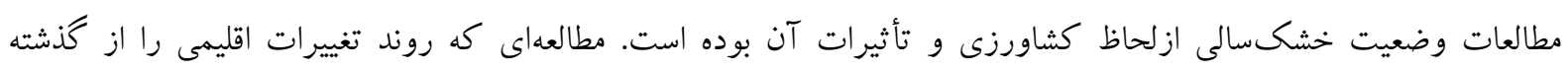

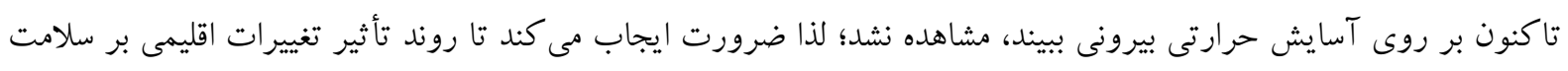

$$
\text { و آسايش حرارتى بيرونى موردتوجه قرار كيرد. }
$$

مطالعات انجامشده در خارج از ايران نيز معطوف به بررسى تأثيرات تغييرات اقليمى بر آسايش حرارتى بيرونى از طريق شاخص

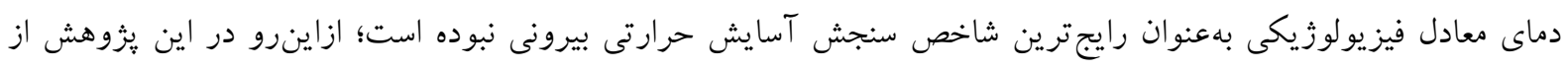

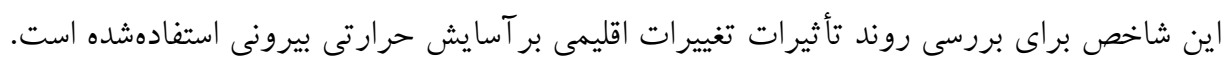

ا مدلى است در جهت محاسبه تراكم شار تابشى، مدتزمان تابش آفتاب و سايه فضاها با استفاده از يكسرى دادهاى ورودى منتج شده از اطلاعات هواشناسى

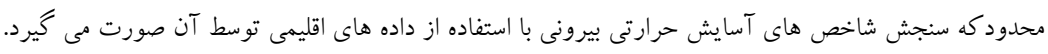




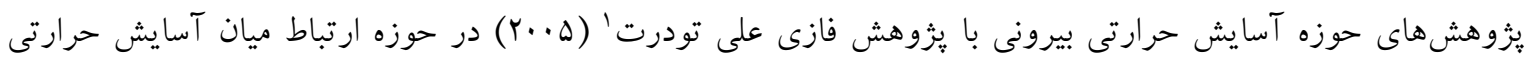

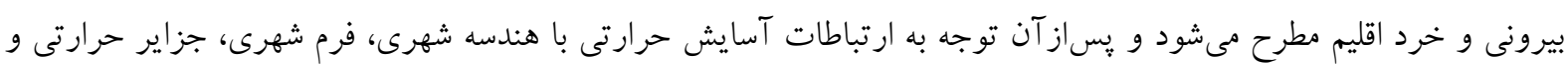
فضاى سبز و تغييرات اقليمى شكل مى گيرد (Ali-Toudert, 2005).

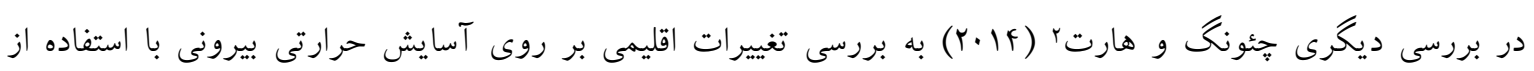

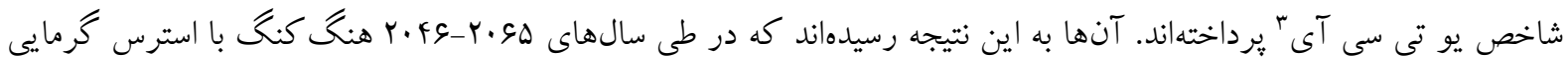

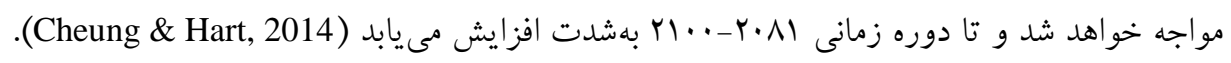
از مطالعات انجامشده در ادبيات جهانى در مورد ارتباط آسايش حرارتى بيرونى و تغييرات اقليمى مى توان به رساله دكترى

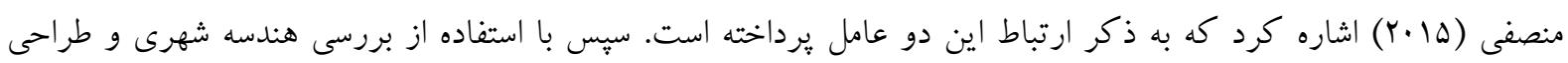

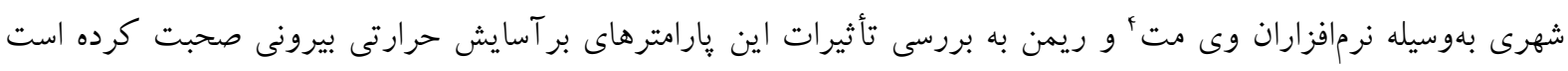

.(Monsefi Parapari, 2015)

در مطالعات داخل ايران نيز كريميان (rوسו) در رساله دكتراى خود با بررسى گونهاى مختلف فضاى سبز به ارائه

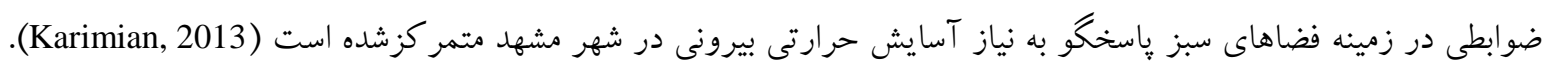

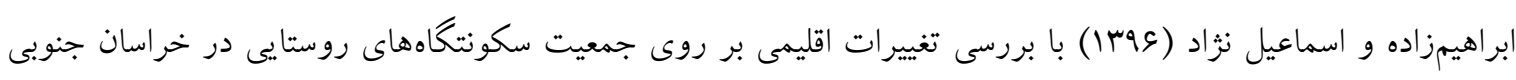

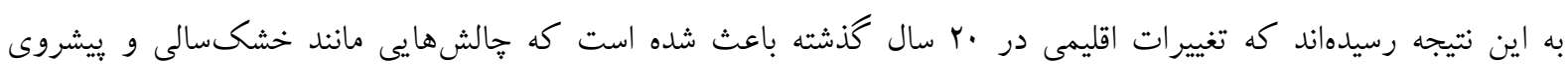
بيابانها در استان بيشتر شود (Ebrahimzadeh \& Esmaeil Negad, 2017). مطالعات انجامشده نشان مىدهد در زمينه تأثيرات تغييرات اقليمى بر آسايش حرارتى بيرونى و سلامت انسان در شهر مشهد

$$
\text { شررسى صورت نخرفته است. }
$$

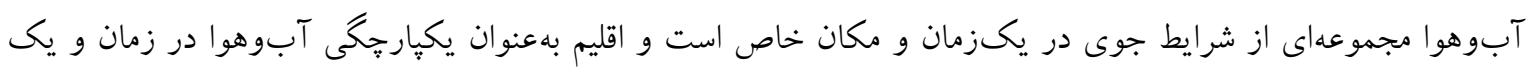

مكان جغرافيايى خاص مطرح مىشود (Draper \& Richards, 2009 Szokolay, 2008). اقليم شهرى، اقليمى است كه حال حاضر شهرها را تحت تأثير قرار مىدهد. طراحى بين ساختمانها و فضاى باز نياز نياز به

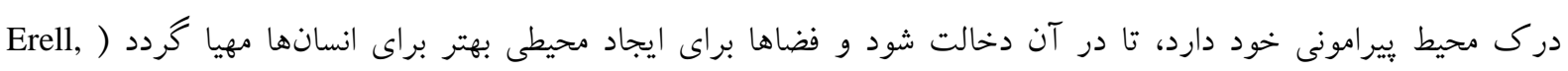

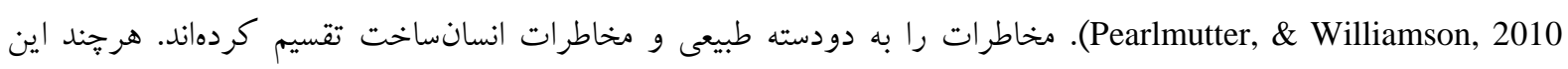

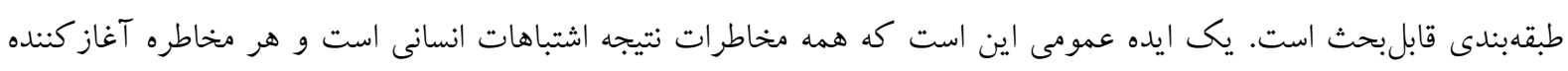
مخاطره ديكر است؛ مثلاً تغييرات اقليمى باعث كرم شدن هوا و ايجاد سيل مى شود (Cimellaro, 2016). بر اين اساس تغييرات اقليمى را مىتوان به دودسته طبيعى و انسانساخت تقسيم نمود. ازنظر طبيعى اين تغييرات از دوره

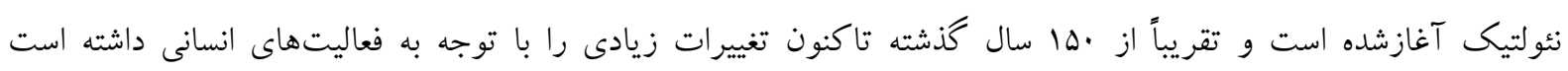

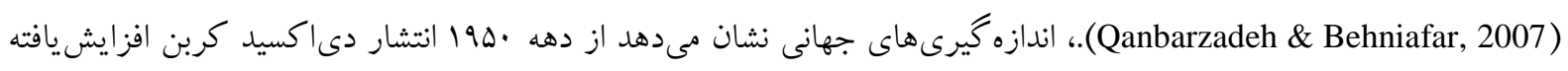




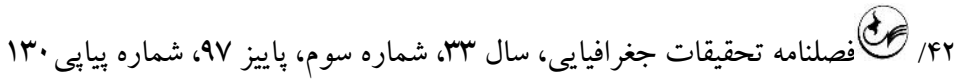

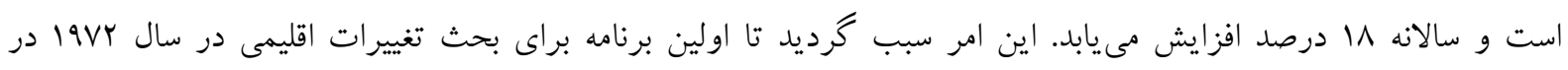
كنفرانس ملى تغييرات اقليمى مطرح گردد (Roaf, Crichton, \& Nicol, 2009).

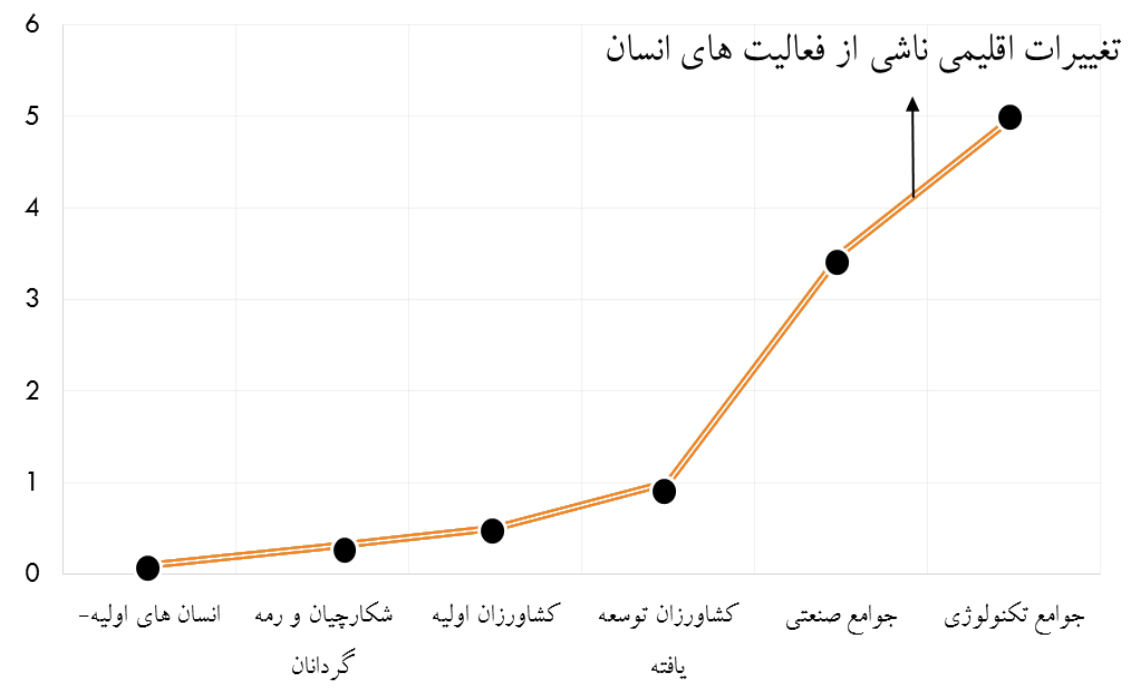

شكل 1- تغييرات محيطى ناشى از فعاليتهاى انسانى

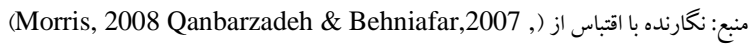

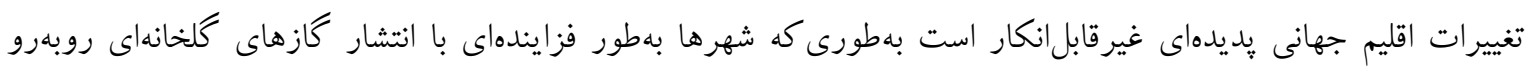
هستند. عواقب ناشى از تغييرات اقليمى بهصورت افزايش سطح حرارت در جو قابلمشاهده است (Prasad et al., 2009). انجمن

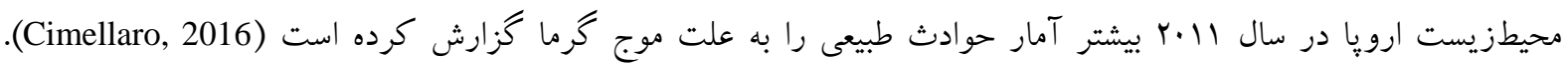

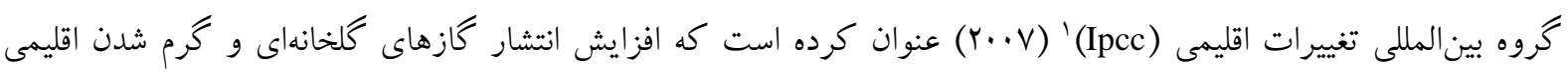

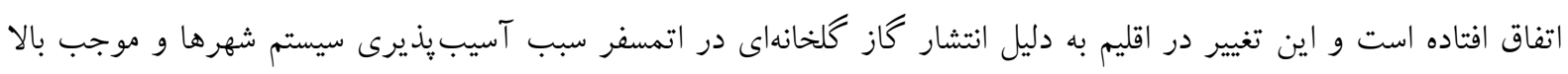

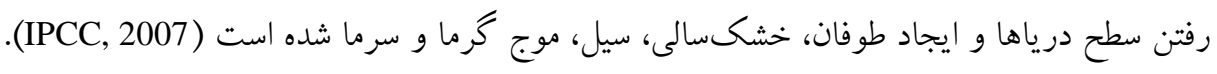

$$
\text { آسايش حرارتى بيرونى }
$$

مطالعات مختلفى در ارتباط با شاخصهاى حرارتى اقليم و ارتباط ميان بدن انسان و محيط يِيرامون انجامشده است و

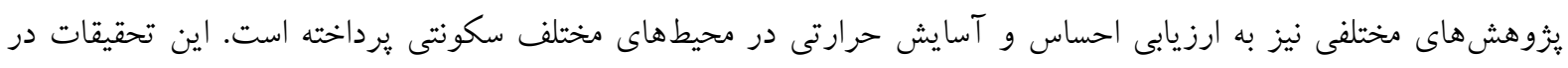

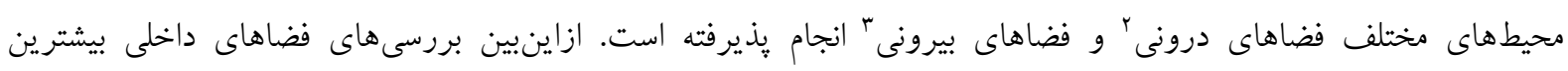

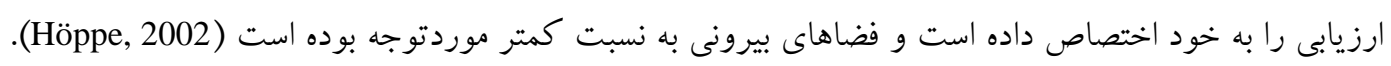

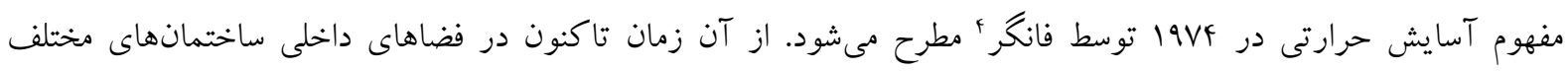

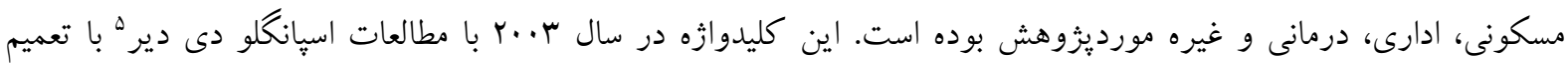

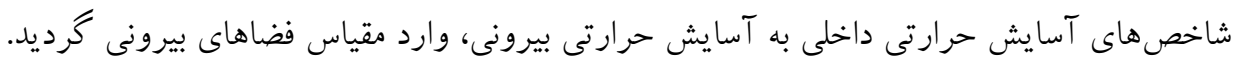

1 The Intergovernmental Panel on Climate Change

2 Indoor

3 Outdoor

4 Fonger

5 Spagnolo and de Dear 
ارزيابى اثرات تغييرات اقليمى بر تغييرات آسايش حرارتى بيرونى با استفاده از ...

از آن به بعد يزوهشهاى مختلف در فضاهاى باز و اقليمهاى مختلف متمر كزشدهاند. جامعه مهندسين گرمايش، سرمايش و تهويه مطبوع آمريكا احساس آسايش حرارتى انسان را، موقعيت استخراج ابراز رضايت از آسايش محيطى كه توسط ارزيابى بهى ذهنى به دست مى آيد، تعريف مى كنند. احساس و ادراك از آسايش مرتبط با وضعيت جسمى فرد، تبادل حرارتى بدن با محيط اطراف و خصوصيات فيزيولوزيكى دارد كه تبادل حرارت بين فرد و محيط اطرافش متأثر از پارامترهاى نظير دماى هوا، رطوبت نسبى، تابش حرارتى (خورشيدى و تابشى)، جريان هوا، ميزان لباس، سطح فعاليت، تماس مستقيم با سطوح مىباشد

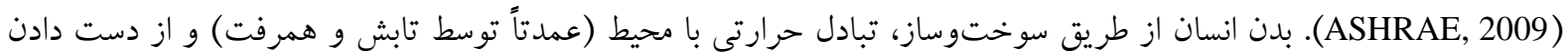
حرارت بهوسيله تبخير مايعات بدن، حرارت توليد مى كند. در طول استراحت طبيعى و ورزش، فر آيندهاى انتقال حرارت منجر

به تغيير درجه حرارت اركانهاى حياتى بدن مىشود (Djongyang, Tchinda, \& Njomo, 2010).

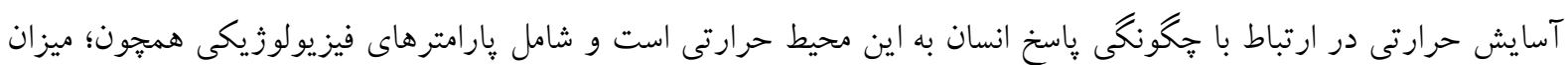
عرق، ضربان قلب، دماى داخلى بدن، دماى يوست و غيره است (Dai, 2014).

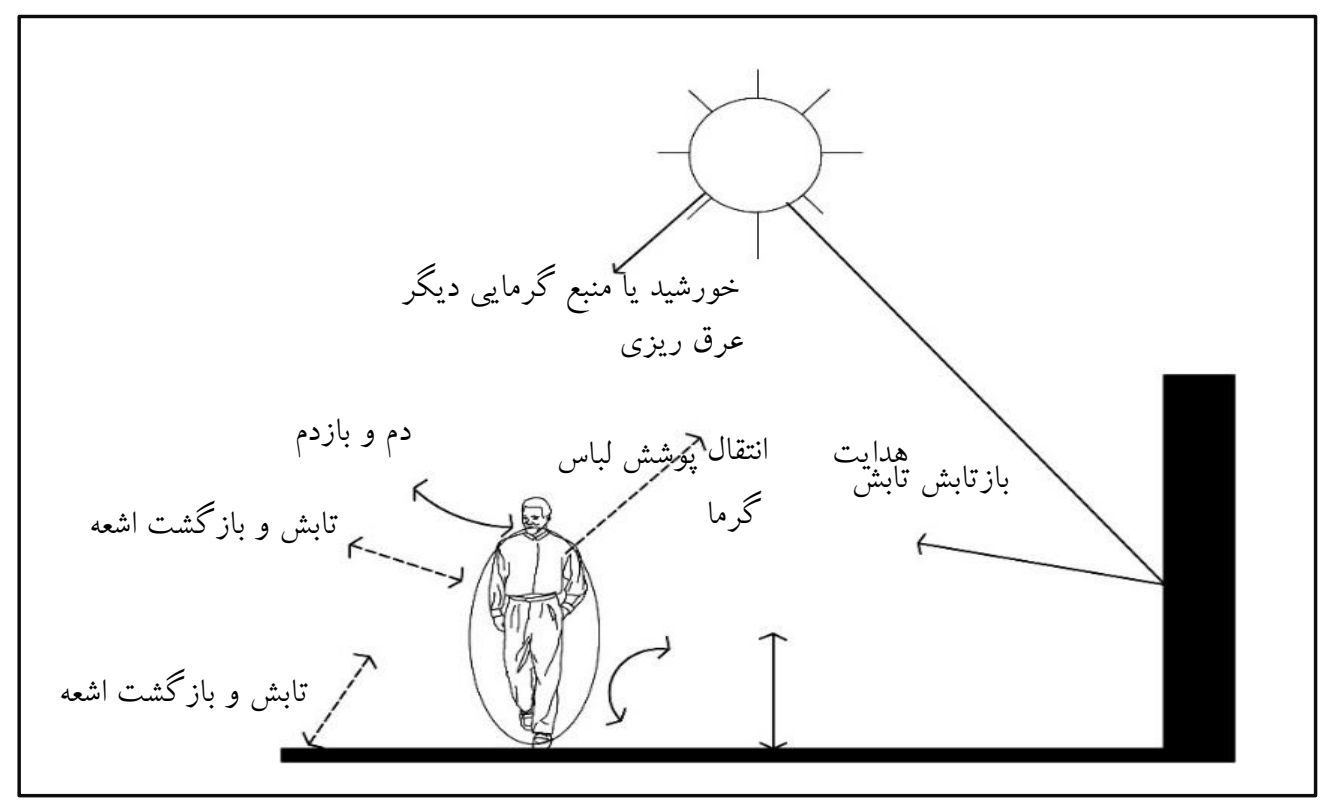

شكل r- اجزا تعادل ترمايع بدن انسان در محيط

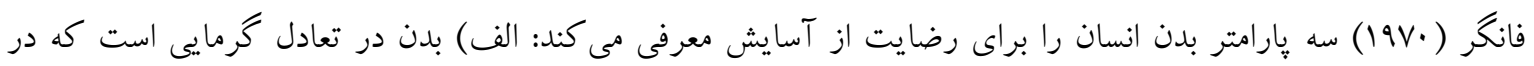

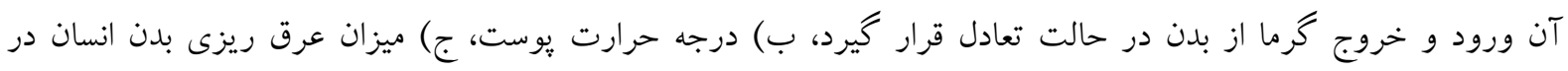

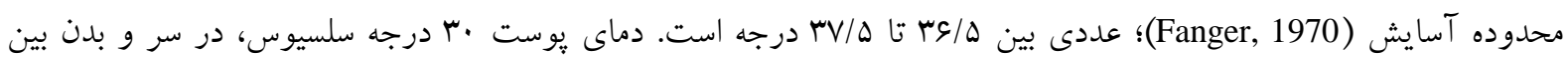

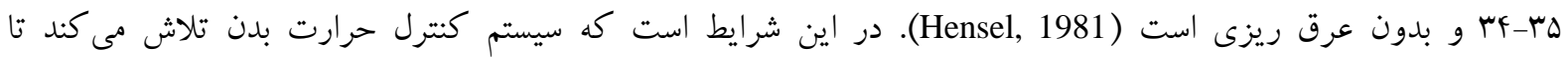
هنكامى كه اختلالات حرارتى رخ مىدهد، اين دما را حفظ كند (Djongyang et al., 2010). فاكتورهاى تأثير گذار بر آسايش حرارتى منابع مختلف عوامل تأثير كذار بر آسايش حرارتى را دستهبندىهاى مختلفى داشتهاند. بررسىهاى اوليه فانكر ( • (19V) در

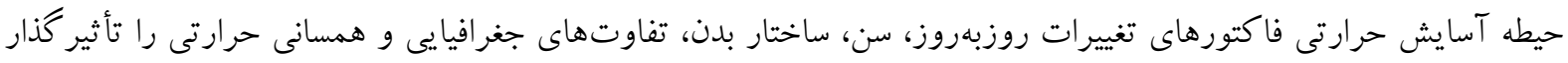

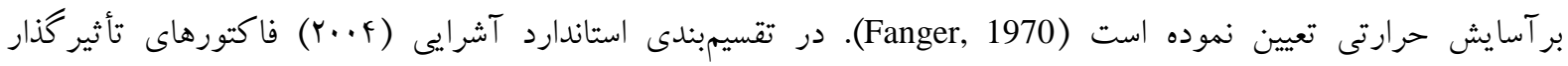




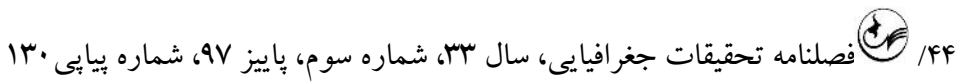

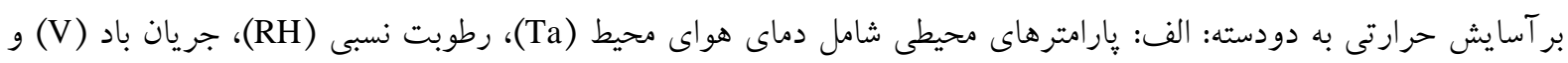

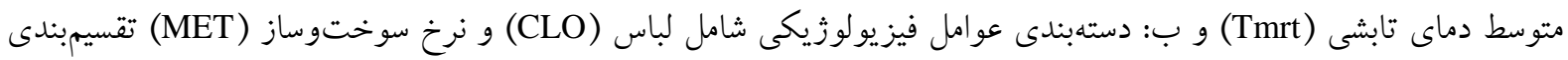

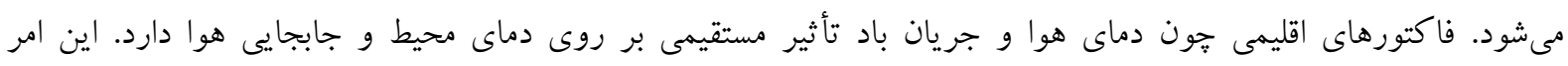

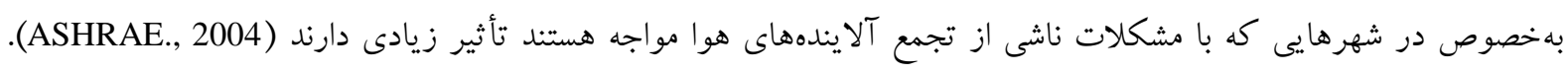

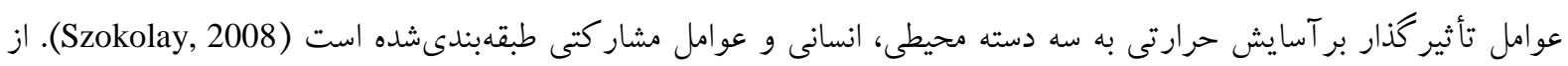

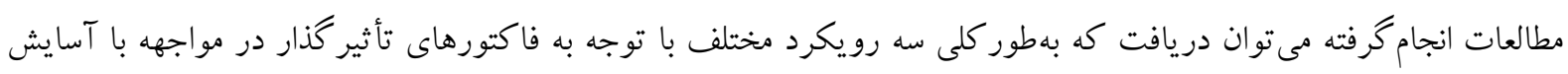

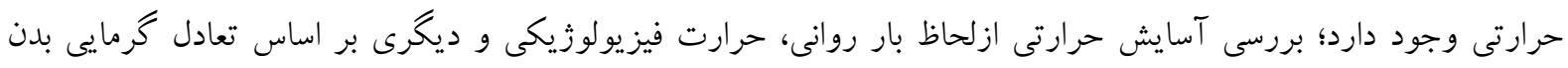

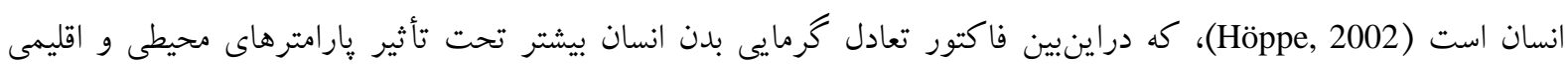
قرار دارد.

شاخصهاى اندازه گيرى آسايش حرارتى را مىتوان در دودسته طبقهبندى نمود. شاخصهاى ساده و تجربى كه شامل هندين

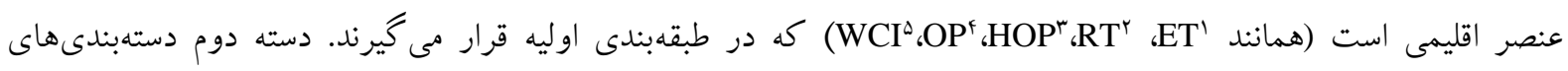

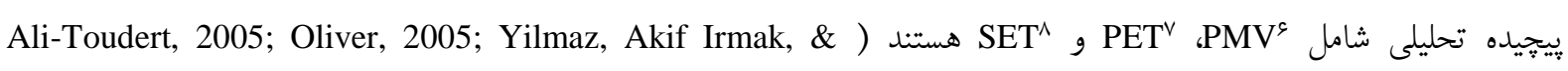

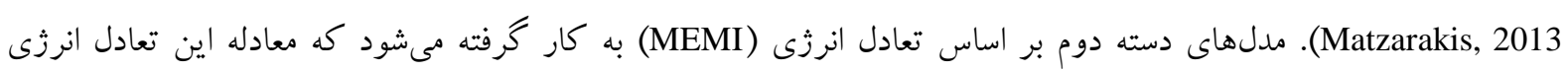
براى بدن انسان عبارت است از:

$\mathrm{M}+\mathrm{W}+\mathrm{R}+\mathrm{C}+\mathrm{ED}+\mathrm{ERC}+\mathrm{ESW}+\mathrm{S}=\mathrm{O}$

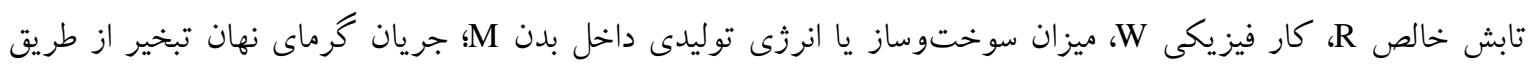

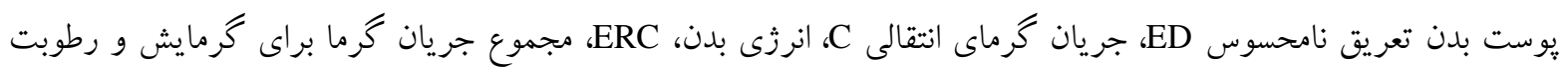

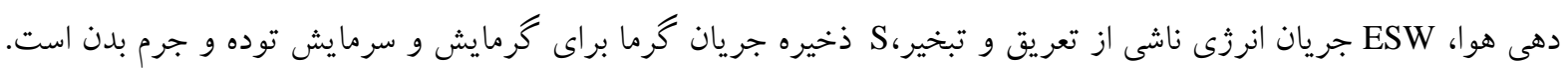

$$
\text { تغييرات اقليمى و آسايش حرارتى بيرونى }
$$

الكوهاى فضايى شهرها، رشد و توسعه آنها تحت تأثير تغييرات اقليمى است. ساختمانها و توسعهاى شهرى، جذب و ونان

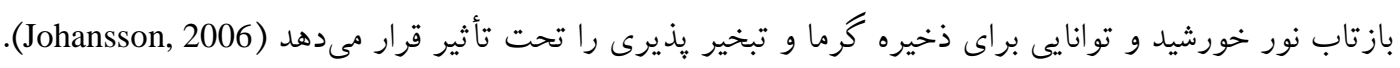

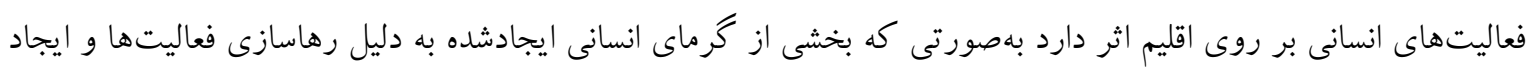

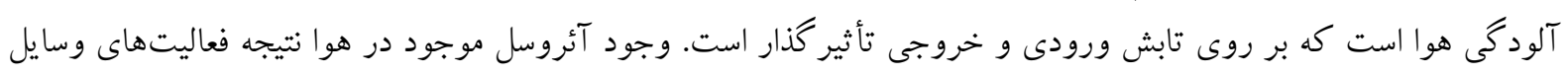

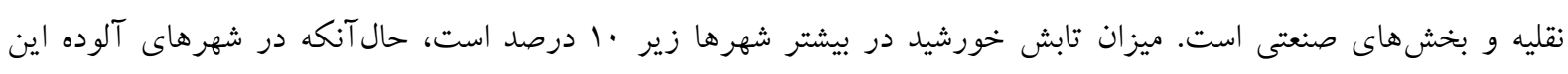

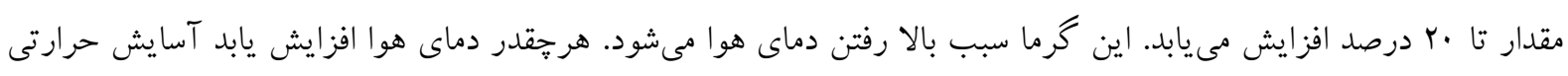

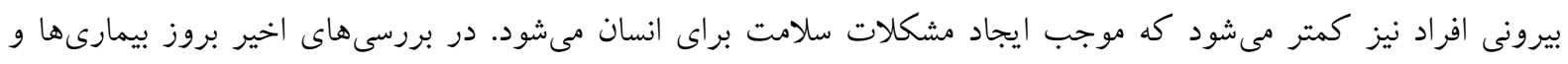

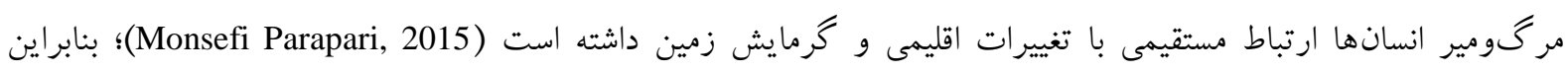

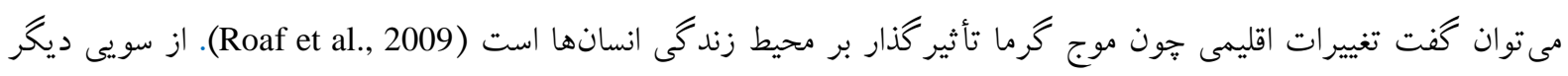

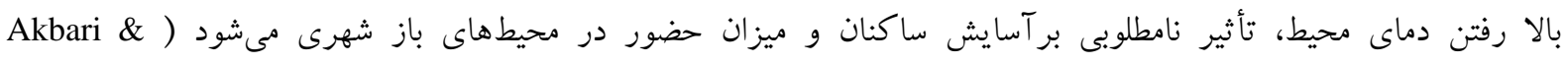

1 Effective Temp

2 Resultant Temp

3 Humid Operative Temp

4 Operative Temp

5 Wind Chill Index

6 Predicted Mean Vote

7 Physiol. Equiv.Temp

8 Stand.Eff.Temp 


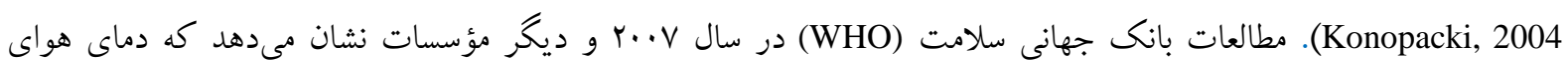

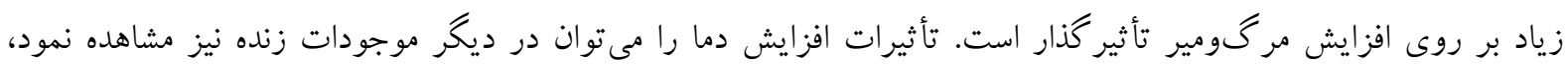

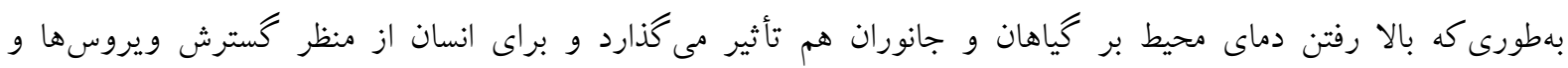

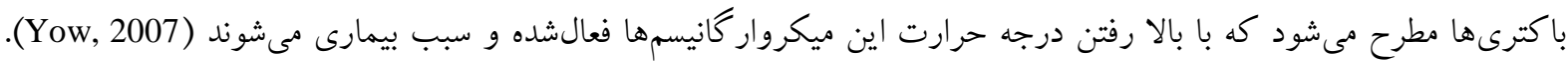

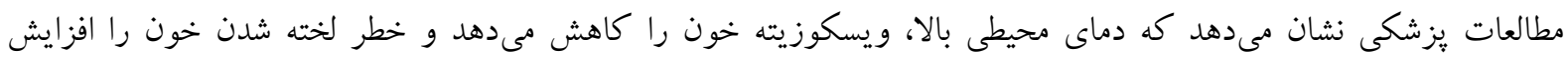

مى دهد. همجنين سبب مشكلات قلبى و تنفسى و مشكلات اختلال در عملكرد كليه ها مى مهود (Linares \& D1'az, 2008). كزارشهاى گسترده نشان مىدهد كه در طى دوره موج گرما و افزايش دماى محيطى، يذيرش بيمارستانها در زمينه

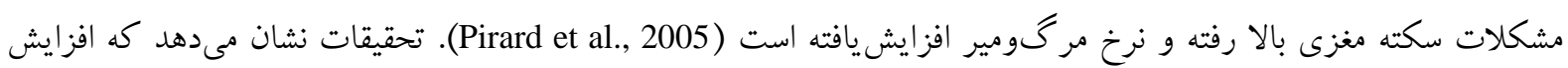

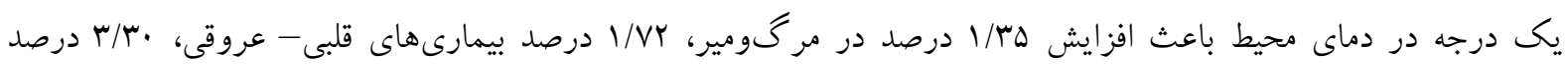
مشكلات تنفسى و 1/Ta درصد عوارض مغزى مى مشود (Analitis et al., 2008).

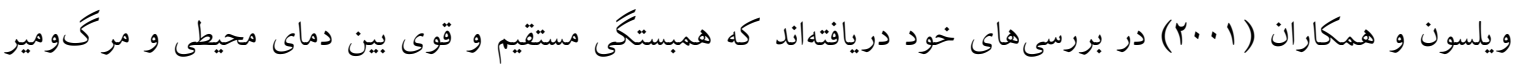

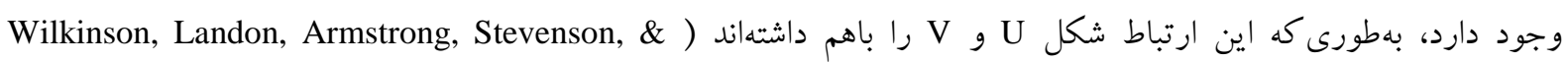

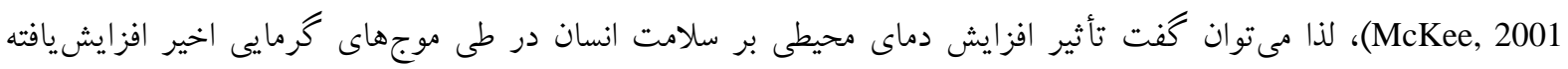

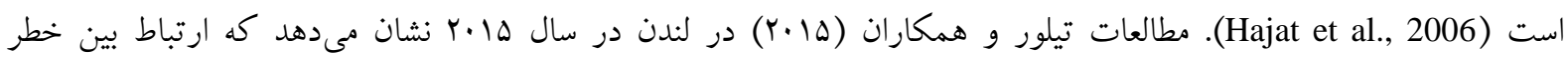

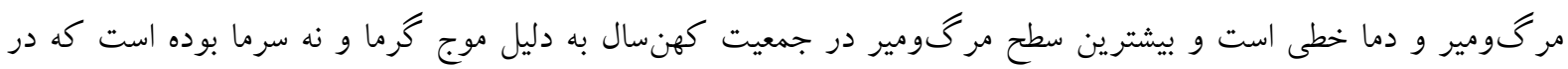

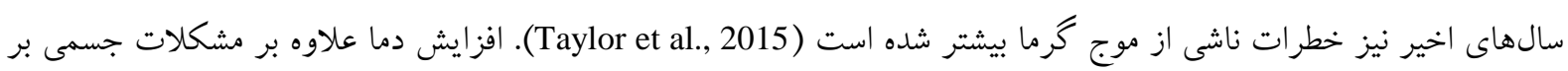

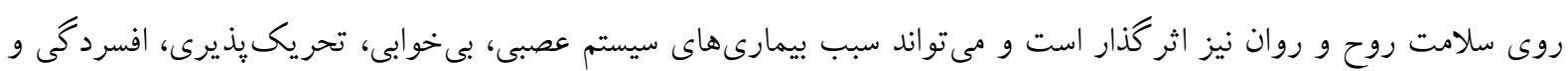
كاهش حافظه نيز شود (Yang, Qian, Song, \& Zheng, 2016). علاوه بر اين گروههاى حساس همجيون افراد سن بالا و كود كان بيشترين افرادى هستند كه در معرض اين خطرات

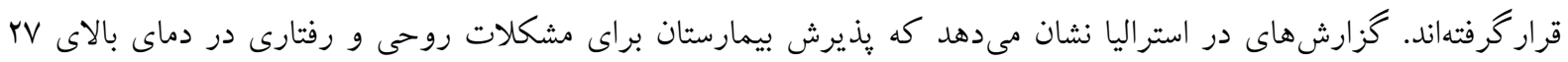

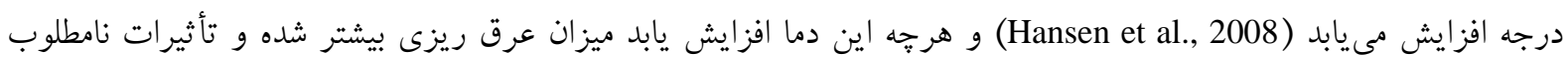
آن بر روى سلامت جسم و روح افزايش مي ميابد. 


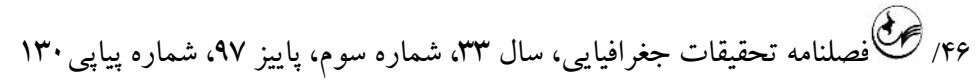

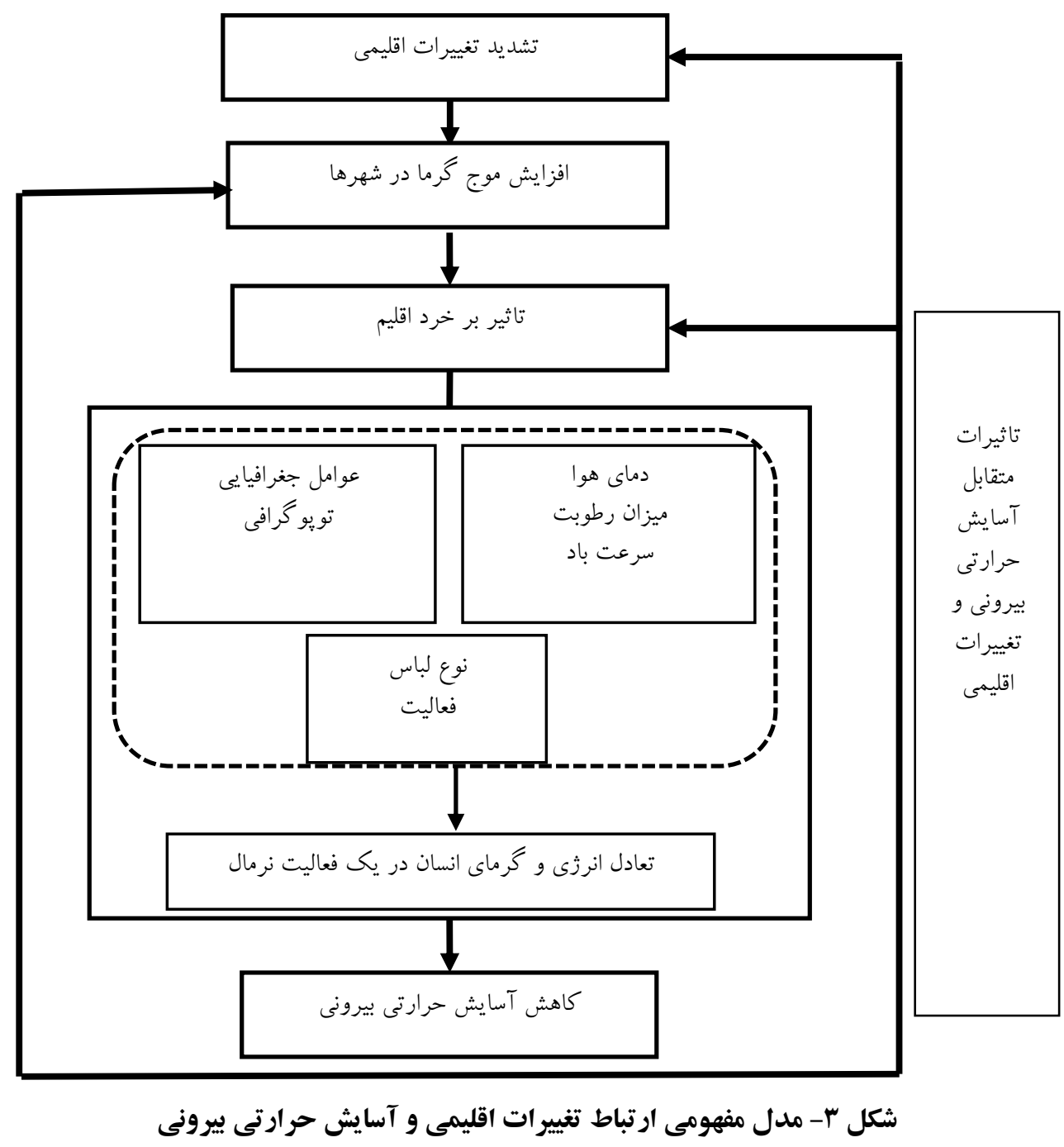

مواد و روشها

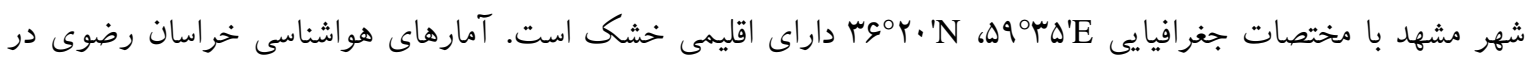

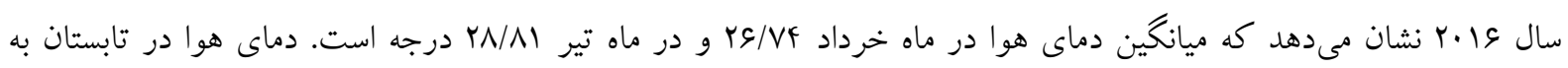

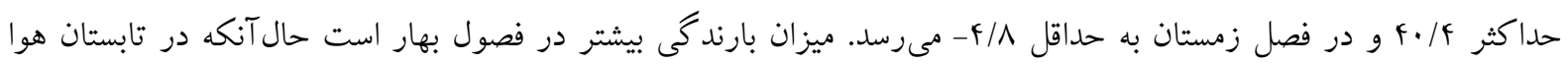

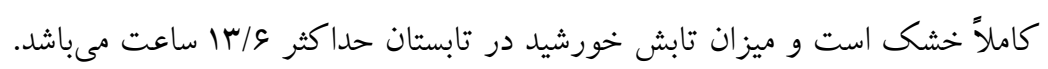
روش تحقيق يزوهش با توجه به ماهيت موضوع، از نوع كاربردى و مبتنى بر دو بخش است. در بخش اول براى تدوين

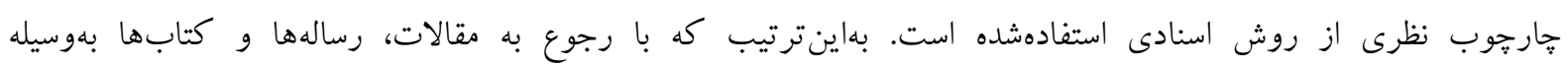

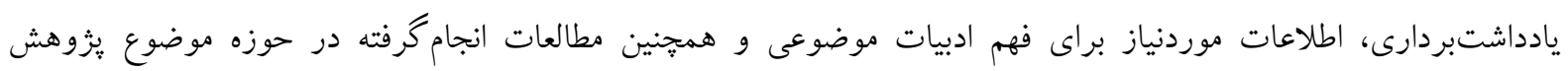

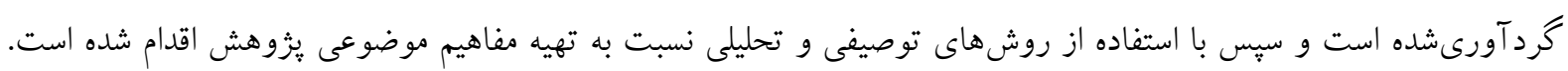

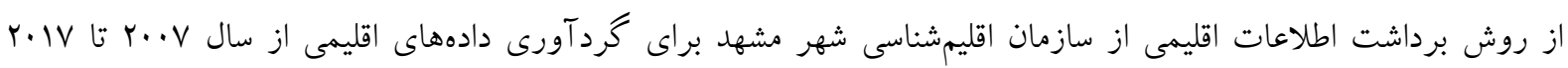
استفادهشده است.

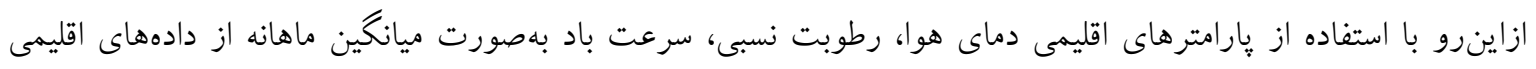

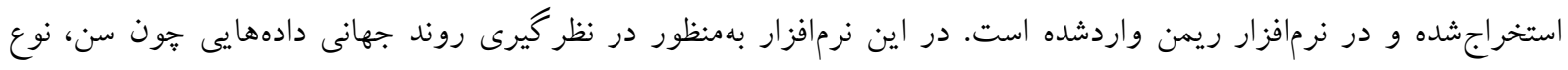


لباس و نوع فعاليت بر اساس استاندارد نرمافزار فرض شده است. دادهايى جون تاريخ، طول و عرض جغرافيايى از ديكر

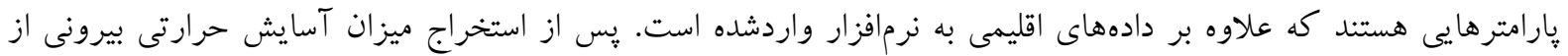
نرم|فزار، دادهها بهنظور تجزيهوتحليل نهايى در نرم|فزار اكسل مورد تجزيهو تحليل واقع شدهاند.

\section{شاخص دماى معادل فيزيولوزيكى}

شاخص دماى معادل فيزيولوزيكى، بهعنوان دماى هوايى كه در شرايط درونى بدون باد و تابش خورشيد تعريف مىشود و

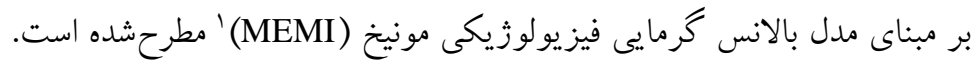

H+C+R+Ep+Esr+Elr+Esw+Ef=S = نرخ جريان خون

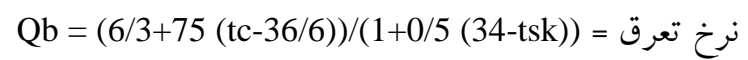
Sw = 8/4710-5 ((1tsk+0/9tc)-35/6)kg/sm² = توليد حرارت تعرو = ترخ

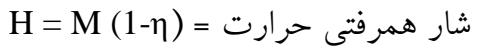

$$
\begin{aligned}
& \text { شار تابشى حرارتى = A = Ask fcl (Ta-Tsk) }
\end{aligned}
$$

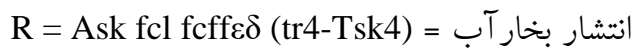

$$
\begin{aligned}
& \text { ED = m r (Pa-Pvsk) = اتلاف تعرق بلوسيله حرارت }
\end{aligned}
$$

Esr = rtm Cp (Ta-Tr) =لاف تعرق بهوسيله حرارت ينهانى

Elr = rtm r (Pa-Pvr)/P = تلاف حرارت بهوسيله تبخير

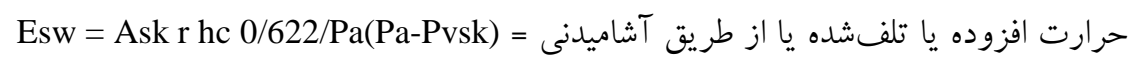

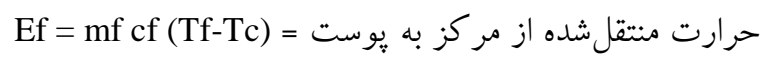

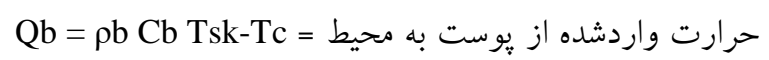

(Tsk-Tcl)/Icl

$$
\text { در معادلات فوق: }
$$

M نرخ سوختوساز (وات بر مترمربع)، S S حرارت خالص ذخيرهده در هسته، $=$ = كار آيى مكانيكى، Ask = سطح

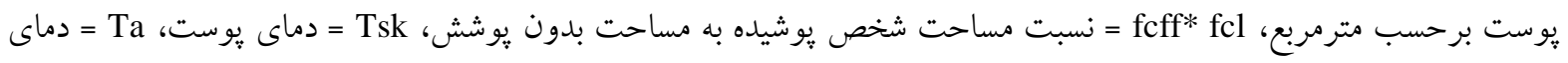

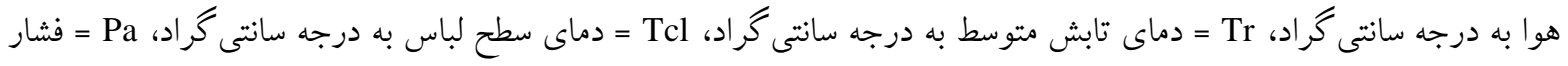

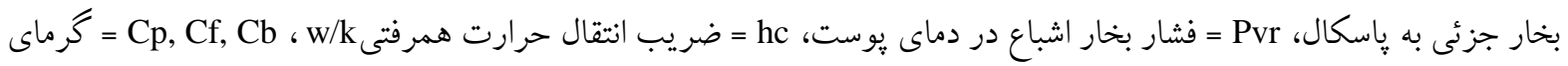

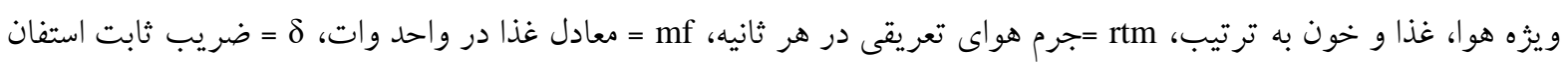

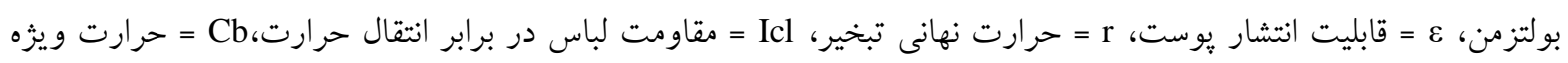

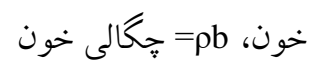

با خروجى هاى اين مدل و حل معادلات تركيبى يارامترهاى اقليمى، فعاليت فيزيكى و نوع يوشش لباس در مدل بالانس

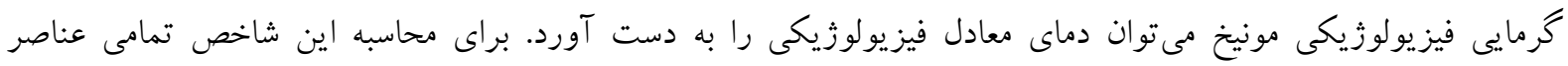

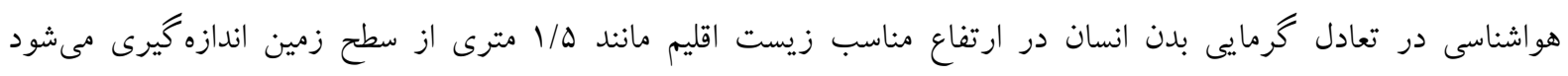

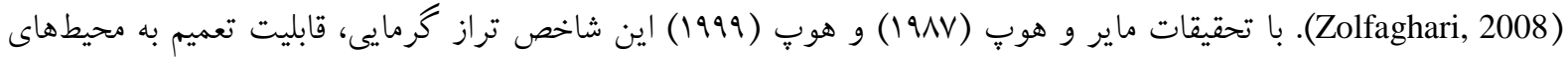

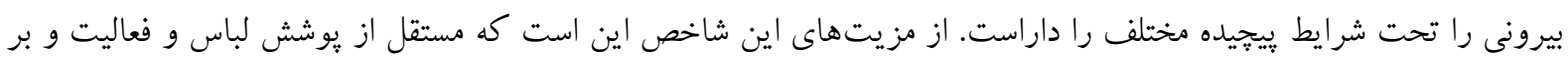




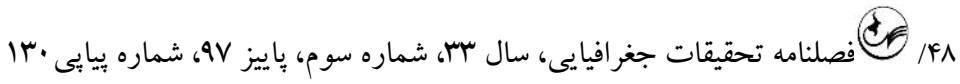
مبناى فرض عدد 9/ · براى سطح يوشش و سطح فعاليتى •^ وات براى افراد مختلف حساب مىشود. از مهمترين عوامل

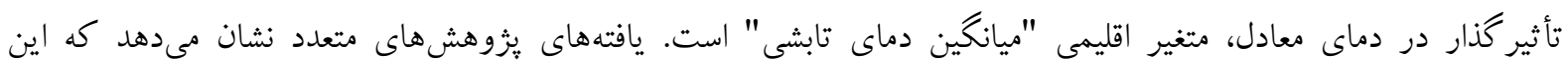

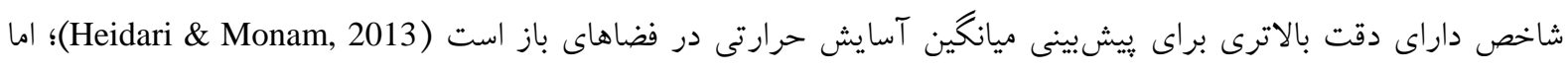

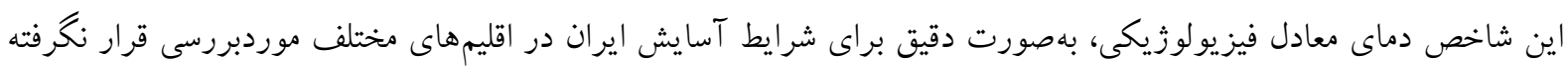

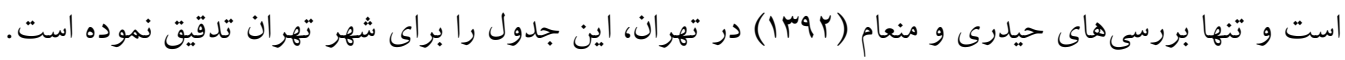
جدول 1- دماى معادل فيزيولوزيكى، احساس حرارتى و درجه استرس فيزيولوزيكى بدن

\begin{tabular}{|c|c|c|c|}
\hline فيزيولوزيكى شهر تهر ان دماى معادل & درجه دماى معادل & ميزان احساس حرارتى & درجه استرس فيزيولوزيكى \\
\hline كمتر از ه/rا & 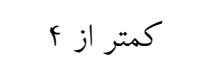 & خيلى سرد & استرس سرماى زياد \\
\hline$|\Psi / \Lambda-| V / \Delta$ & $k-\Lambda$ & 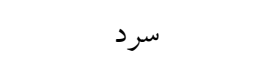 & استرس سرماى قوى \\
\hline$|V / \Delta-Y| / \mid$ & $\Lambda-14$ & 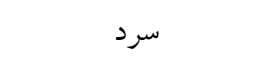 & استرس سرماى معتدل \\
\hline$r M / I-r F / \Lambda$ & $|r-| \mid$ & كمى سرد & استرس سرماى ملايم \\
\hline$r F / A-T N / F$ & M-r & آسايش & عدم وجود استرس حرارتى \\
\hline$r N / F-r Y / I$ & Q & كمى گرم & استرس گرماى ملايم \\
\hline$r r / I-r \Delta / V$ & rq-ro & 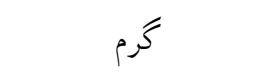 & استرس گرمايى متوسط \\
\hline$r \Delta / v-r q / f$ & $r_{\Delta-f-}$ & داغ & استرس گرمايى قوى \\
\hline بيشتر از \&/F & بيشتر از ||F & بسيار داغ & استرس گرمايى زياد \\
\hline
\end{tabular}

منبع: (Heidari \& Monam, 2013Matzarakis, Mayer, \& Rutz, 2002)

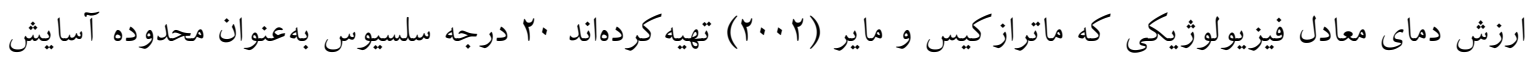

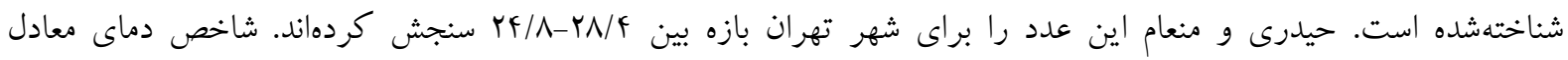

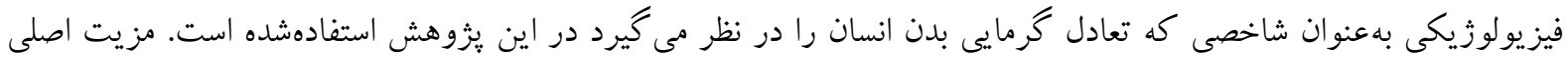

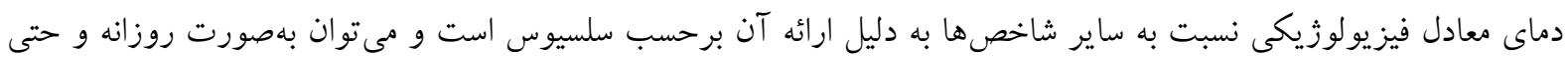

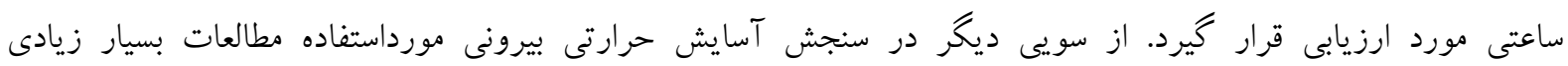

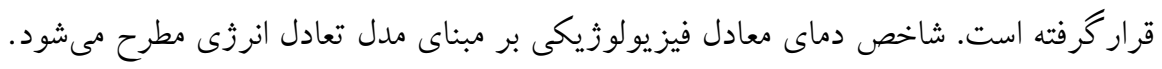

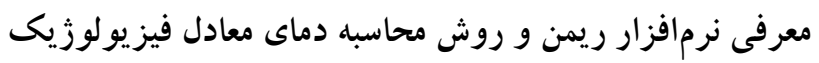

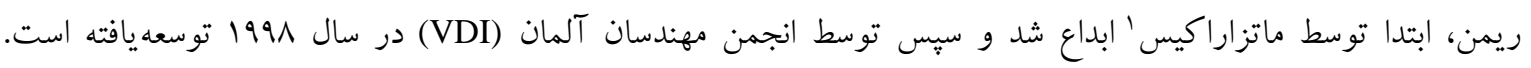

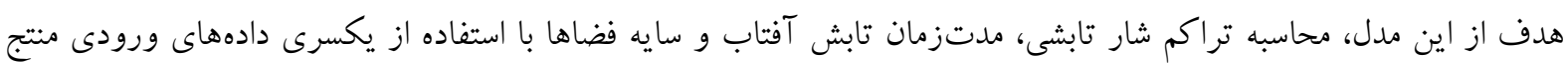
شده از اطلاعات هواشناسى محدود است. ورودى دادههاى ريمن اين مدل، شار تابش را در محيطهاى ساده و يِيجيده و بر مبناى جند پارامتر مختلف محاسبه مى كند: 
- دادهاى تويو كرافى شامل طول و عرض جغرافيايى و ارتفاع محل ايستخاه هواشناسى.

- - دادهاى هواشناسى مانند دماى هوا، فشار بخار، رطوبت هوا، سرعت نسبى، ميزان ابرناكى آسمان.

$$
\text { - دادههاى انسانى: قده، وزن، سن، جنسيت. }
$$

- دادهاى مرفولوزيكى محيطى شامل ساختمانها، درختان هميشهسبز و خزان يذير.

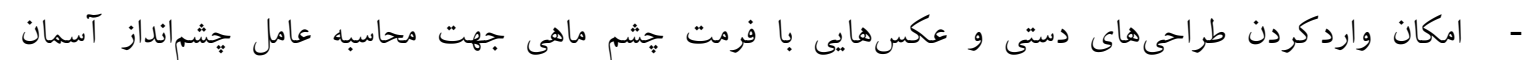

.(Matzarakis, Rutz, \& Mayer, 2010)

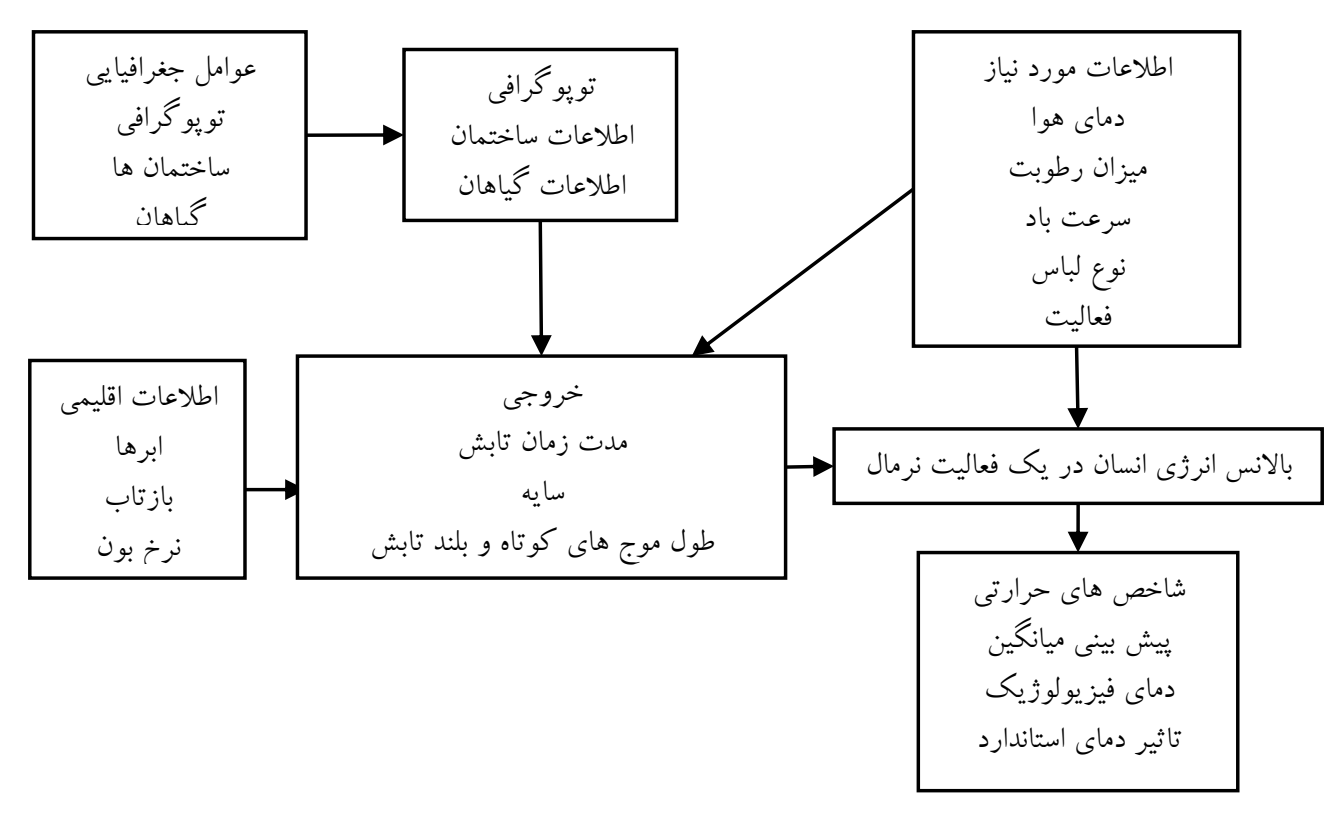

شكل f - ساختار بيو كليمالوزيك انسانى مدل ريمن

منبع: (Matzarakis et al., 2002)

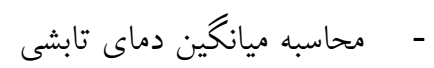

- - قابليت محاسبه خورشيد در هرروز از سال و نمايش جغرافيايى

- ايجاد سايه در موانع شهرى و طبيعى در هرروز از سال و هر دوره خاصى از روز بهمنظور كمى كردن فضاهايى كه سايه در آن ايجادشده است.

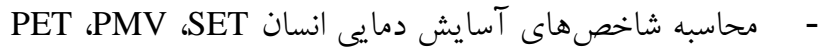

$$
\text { كاربرد نرمافزار ريمن }
$$

- برنامهريزى شهرى و منظر (با توجه به بررسى اثرات يروزههاى بزرگ) - بخش كردشخرى (انتخاب زمانهاى تعطيلات) - ارائه يیشنهاد براى محل مناطق مسكونى - تغييرات اقليمى مرتبط با بيومترولوزى انسانى - آبووهوا و سلامت (براى تجزيهو تحليل موقعيتهاى حرارتى) 


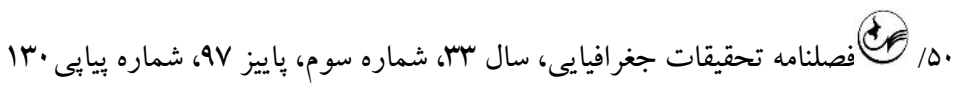

- كشاورزى و هواشناسى (محاسبه شار تابش در محيطهاى مختلط)

- اكولوزى منظر (بر آورد فر آيندهاى طبيعت) (Matzarakis et al., 2002) -

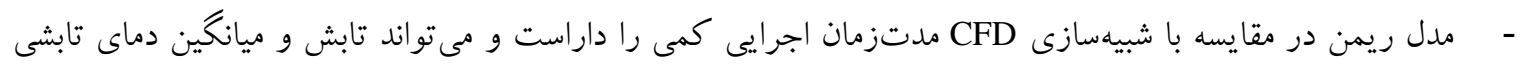

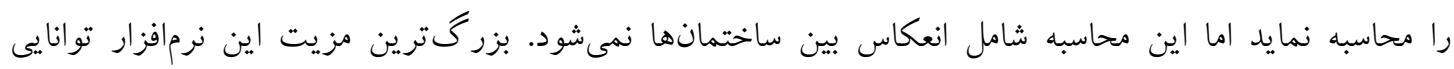

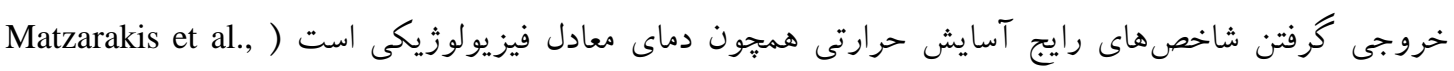

يافتههاى يزو هش

\section{تغييرات شاخص دماى معادل فيزيولوزيك در شهر مشهد}

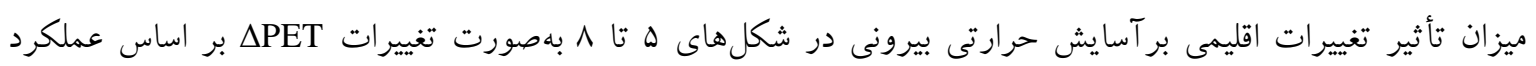

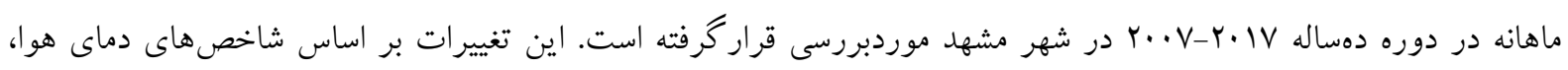

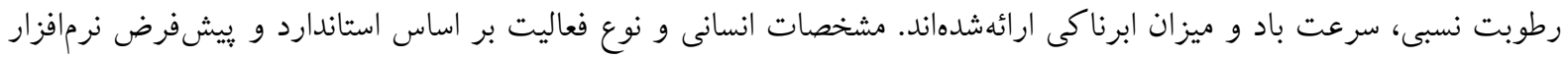

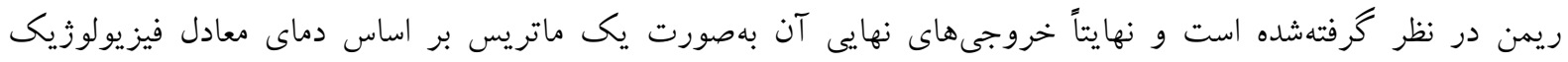

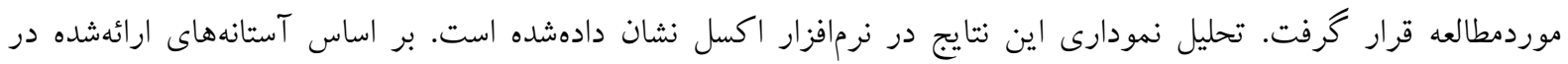

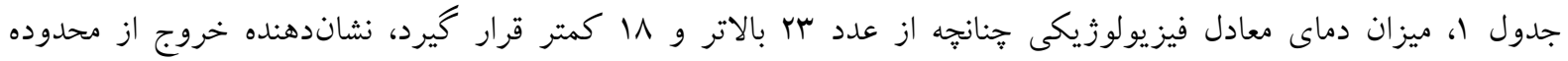

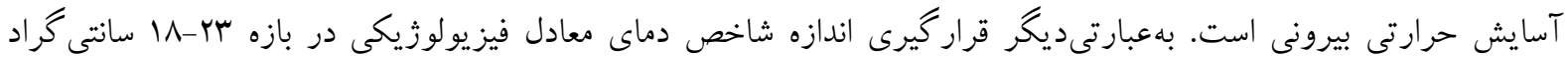

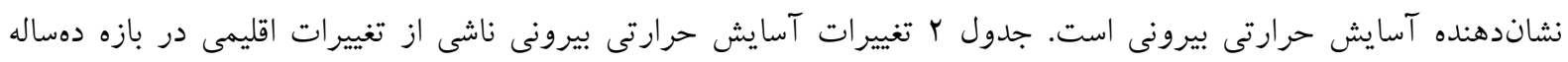

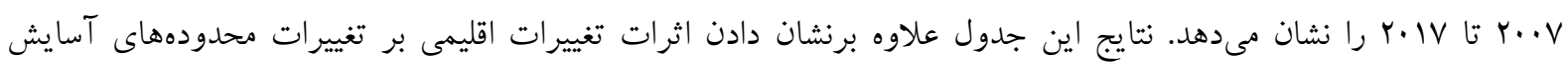

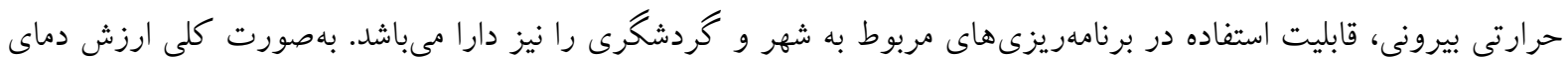

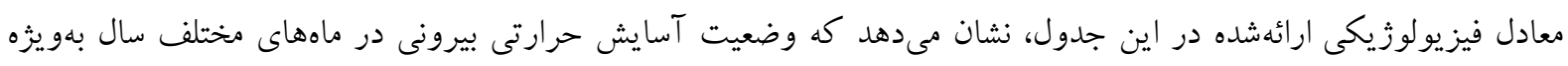

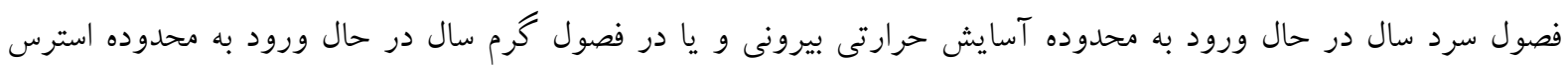

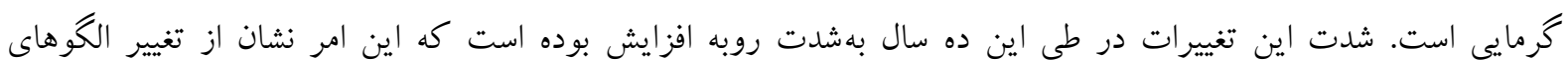
تغييرات اقليمى و شدت موج گرما در شهر مشهد را دارد. 


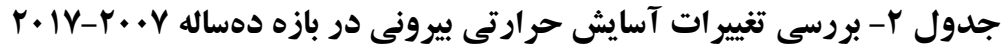

\begin{tabular}{|c|c|c|c|c|c|c|c|c|c|c|c|}
\hline$r . I V$ & $r .1 s$ & $r \cdot 10$ & $r \cdot I f$ & $r \cdot i r$ & $r \cdot I r$ & $r .11$ & $r .1$. & $r \cdot q q$ & $r \cdots \Lambda$ & $r \cdots v$ & ماه \\
\hline$-F / D$ & -1 & $-r / \Delta$ & $-F / r$ & $-f / \varepsilon$ & $-8 / 9$ & $-f / 1$ & $-1 / V$ & $-\omega$ & $-10 / 1$ & $V / \mu$ & دى \\
\hline$-0 / 9$ & $\cdot / 1$ & $-\cdot / 8$ & $-V / \mu$ & $-\cdot / \mu$ & $-\Delta / \Lambda$ & $-\Delta / \Delta$ & $-Y / I$ & $-\cdot / 1$ & $-6 / 9$ & $-1 / 8$ & بهمن \\
\hline $1 / 9$ & $F / D$ & $\cdot / f$ & $1 / f$ & $r / s$ & $\cdot / V$ & $1 / f$ & $f / D$ & $f / \Delta$ & $V / V$ & $\cdot / 0$ & اسفند \\
\hline$\Lambda / \Delta$ & $\Lambda / 1$ & $1 . / 9$ & $N / \Delta$ & $V / f$ & $11 / 1$ & $1 / f$ & $9 / 9$ & $f / f$ & $11 / r$ & $1 \cdot / 9$ & فروردين \\
\hline$r \cdot / \Delta$ & $1 s / V$ & $1 \varepsilon / 1$ & $18 / 0$ & $1 F / 0$ & $1 f / 9$ & $I V / r$ & $10 / 1$ & $\mid f / s$ & $18 / 8$ & $10 / r$ & ارديبهشت \\
\hline$r Y / l$ & $r \cdot / f$ & $r Y / S$ & $r Y / r$ & $r \cdot / \Delta$ & $r \cdot / l$ & $r Y / 9$ & $r I / \varepsilon$ & $1 N / 1$ & $r \cdot / \Lambda$ & $r \cdot / f$ & خرداد \\
\hline$r \pi / s$ & $r \pi / r$ & MF & $r y / q$ & $M / s$ & $r \mu / r$ & $r / r$ & $r / r$ & $r Y / r$ & r & $r Y / D$ & تير \\
\hline$r \cdot / r$ & $r$. & $r \cdot / r$ & $r M / r$ & $19 / V$ & $r M / r$ & $r \mid / s$ & $r \cdot / r$ & $r \cdot / r$ & $r \cdot / F$ & $r \cdot / r$ & مرداد \\
\hline $1 s / f$ & $1 V / 9$ & $1 f / D$ & IV & $\mid \Lambda / \mu$ & $|f /| \varepsilon$ & $10 / V$ & $\mid f / \mu$ & $1 F / 9$ & $10 / f$ & $1 f / A$ & شهريور \\
\hline$q / f$ & $s / 8$ & $1 \cdot / 1$ & $V / I$ & $\Lambda / 1$ & $9 / 0$ & $\Lambda / \Delta$ & $\mid r / 1$ & $V / q$ & V & $s / D$ & مهر \\
\hline$f / D$ & $-\cdot / 1$ & $1 / 0$ & $-\cdot / \mu$ & $r / V$ & $r / F$ & $-1 / 9$ & $r / V$ & $1 / 8$ & $\cdot 10$ & $f / r$ & آبان \\
\hline$-r / \mu$ & $-1 / 0$ & $-Y / \Lambda$ & $-r / F$ & $-F / \varepsilon$ & $-f$ & $-Q / V$ & $-1 / \mu$ & $-1 / \mu$ & $-r / \Lambda$ & $-F / r$ & آذر \\
\hline
\end{tabular}

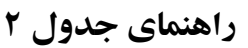

\begin{tabular}{|c|c|c|c|c|c|c|c|c|c|}
\hline بسيار & داغ & كرم & كمى كرم & آسايش & سمى سرد & معتدل & سرد قوى & خيلى سرد & ميزان احساس حرارتى \\
\hline بيشتر از & $\mid \vec{\Delta}-f_{l}$ & $r q-r_{D}$ & $r m-r q$ & $|\Lambda-r|$ & $\mid r-11$ & $\Lambda-1 r$ & $f-\Lambda$ & كمتر از ؟ & درجه دماى معادل \\
\hline
\end{tabular}

ميزان تأثير تغييرات اقليمى بر آسايش حرارتى بيرونى در فصل بهار

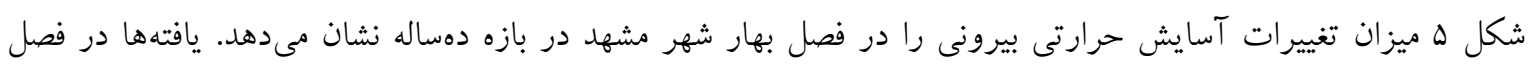

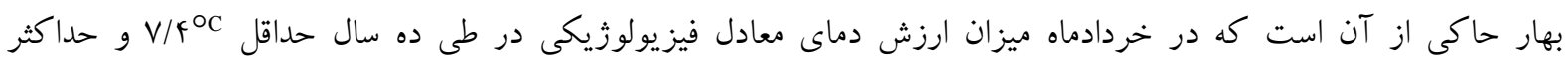

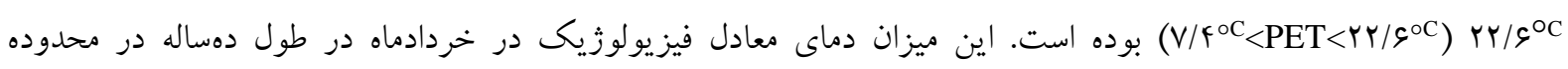

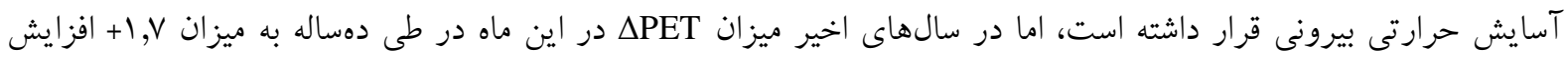

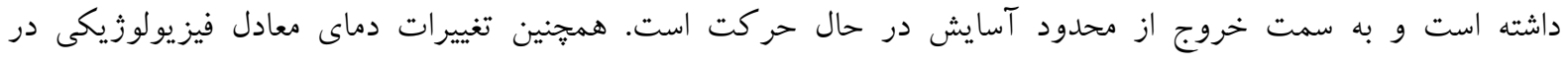
فروردينماه در اين مدت بين (V/

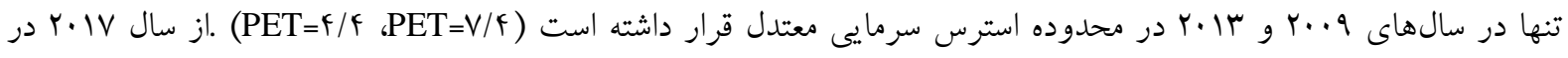

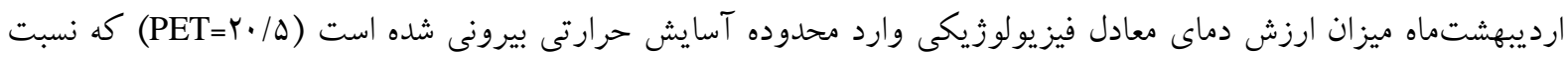

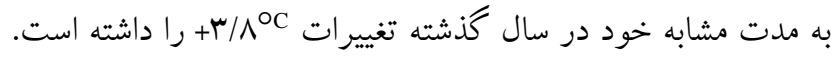




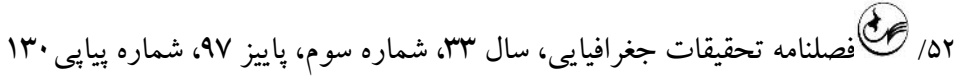

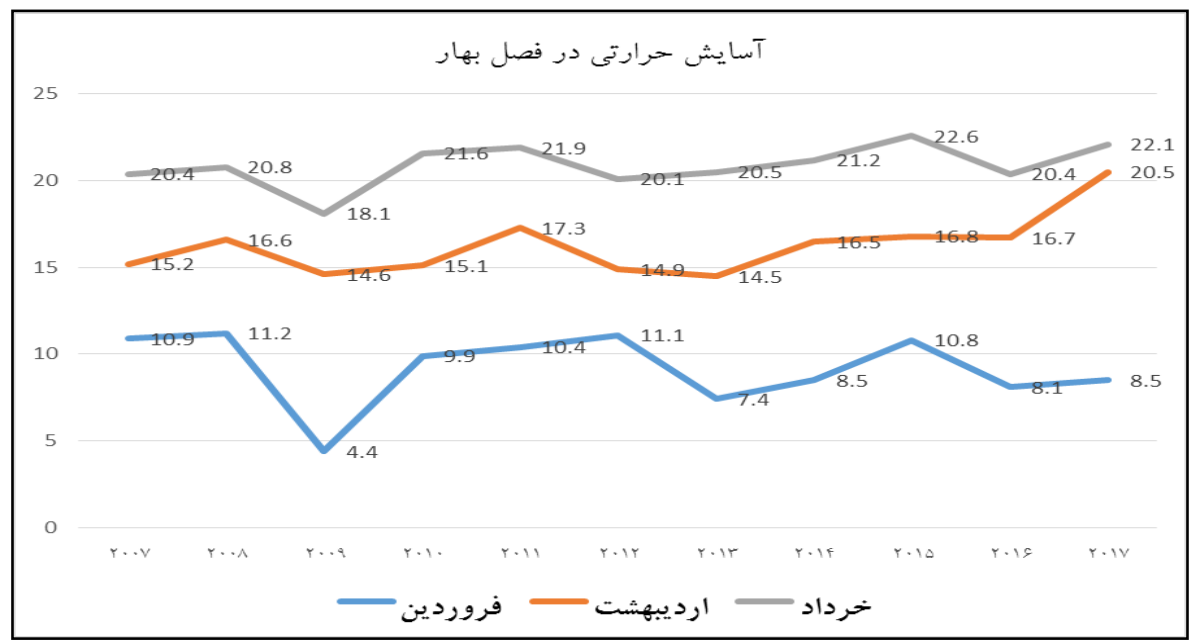

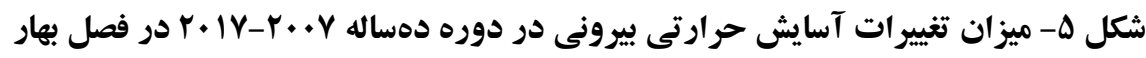

ميزان تأثير تغييرات اقليمى برآسايش حرارتى بيرونى در فصل تابستان

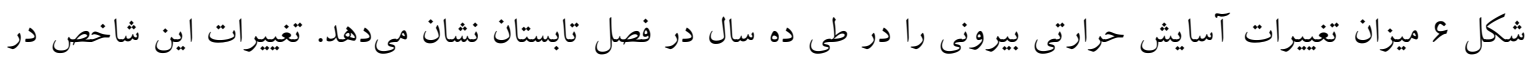

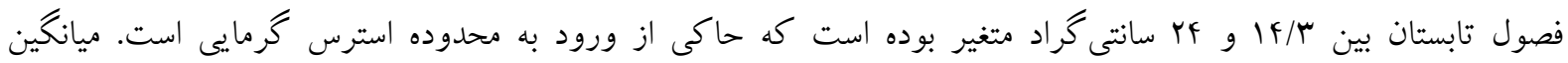

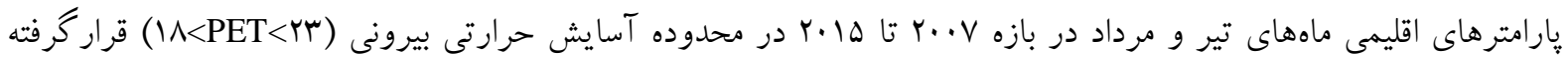

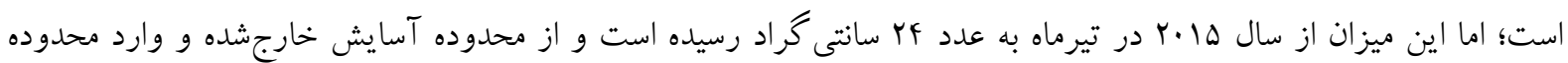

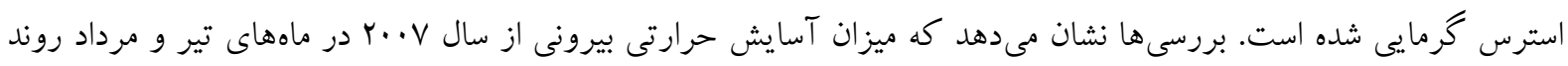

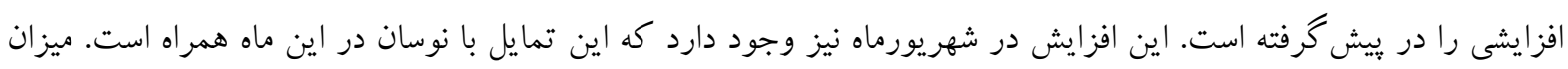

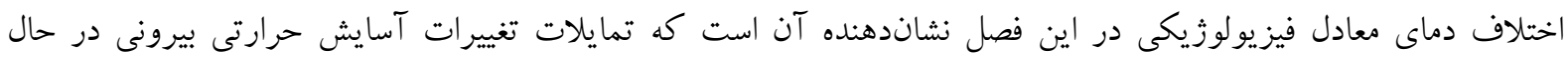

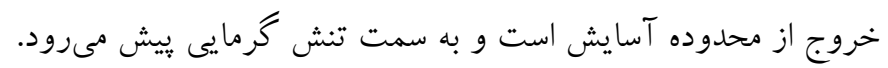

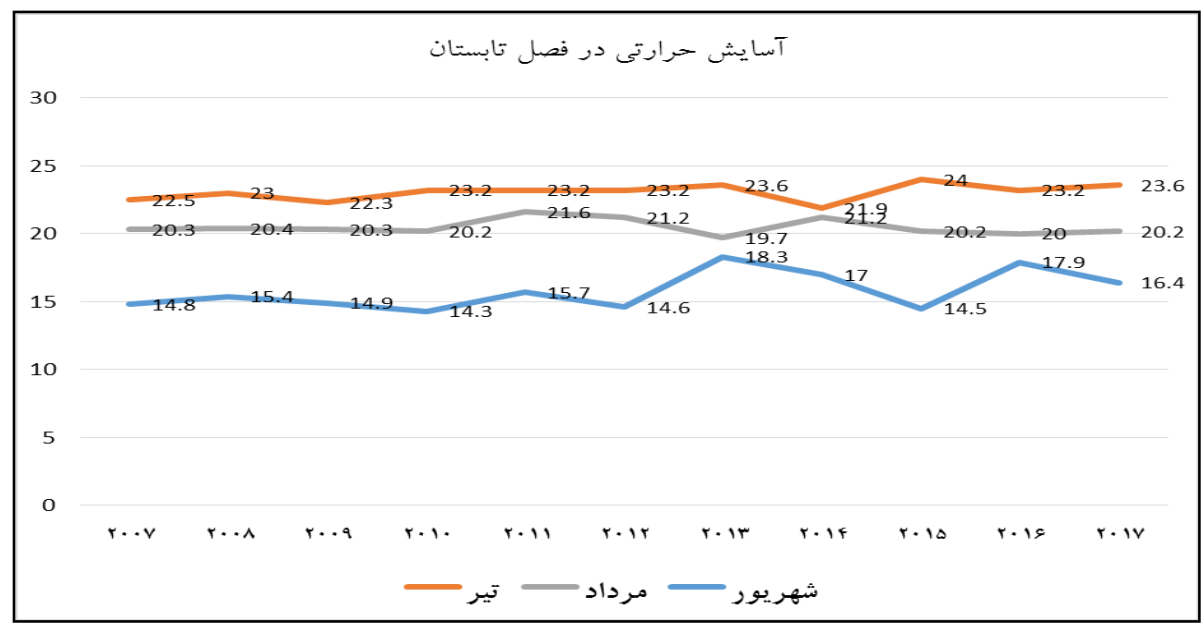

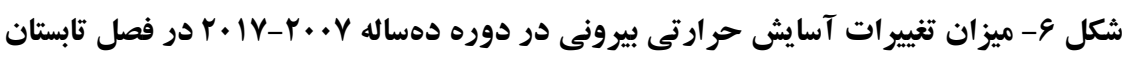

ميزان تأثير تغييرات اقليمى برآسايش حرارتى بيرونى در فصل باييز تغييرات آسايش حرارتى بيرونى در فصول پاييز نشان مىدهد كه ماههاى اين فصل داراى نوساناتى در محدوده استرس

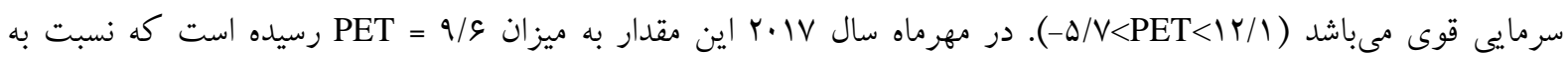




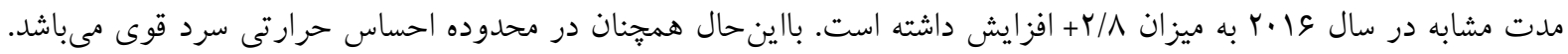
در آبان ماه ميزان تغييرات دماى معادل فيزيولوزيك نوساناتى را در طى ده سال شاهد بوده است. بررسىها نشان مىدهد كه تا

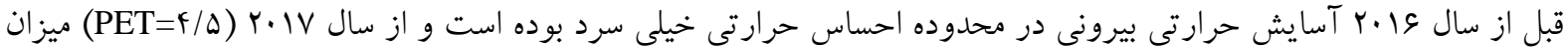
اين شاخص افزايش يافته و به سمت محدوده احساس حرارتى سرد بيش رفته است.

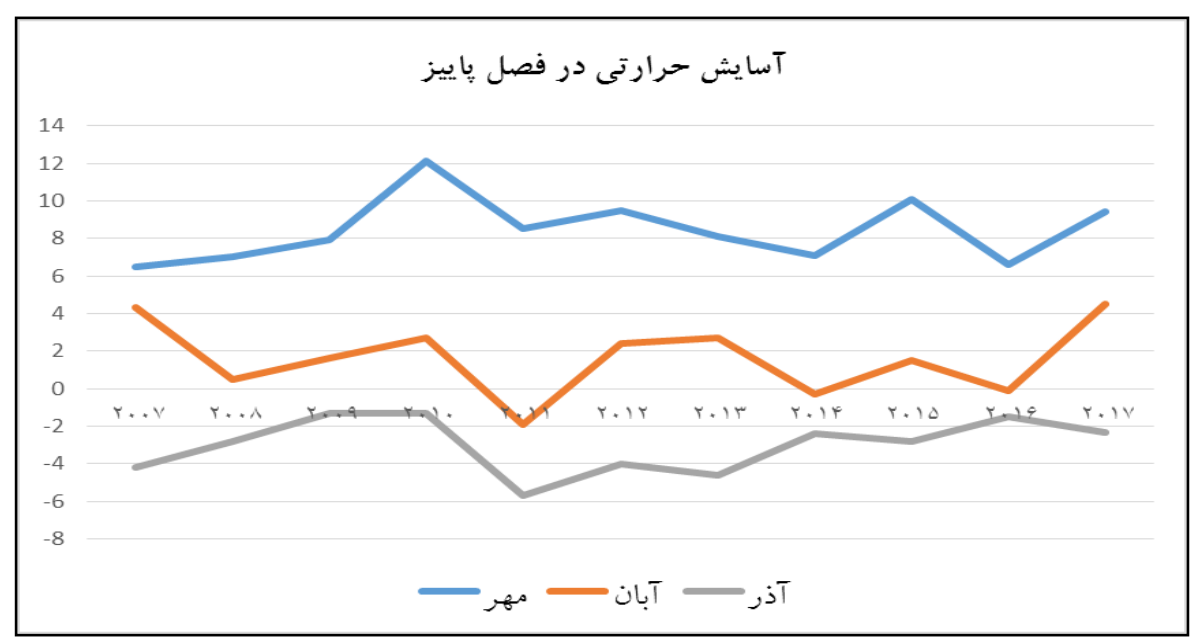

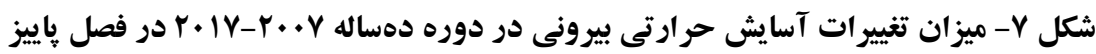

ميزان تأثير تغييرات اقليمى برآسايش حرارتى بيرونى در فصل زمستان

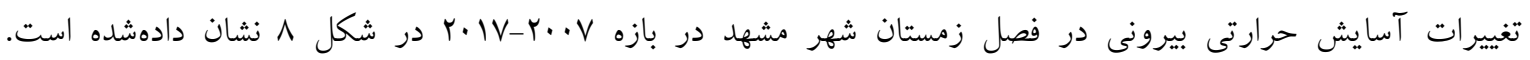

از آنجايى كه در دستهبندى محدوده آسايش حرارتى بيرونى جنانجه ارزش دماى معادل فيزيولوزيكى كمتر از \| باشد به سمت محدوده تنش سرمايى در حال حر كت است؛ بررسىهاى تغييرات دماى معادل فيزيولوزيكى در اين فصول نشان مىدهد كه اين

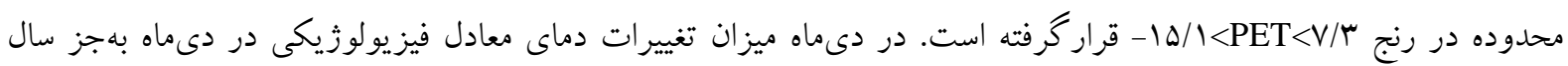

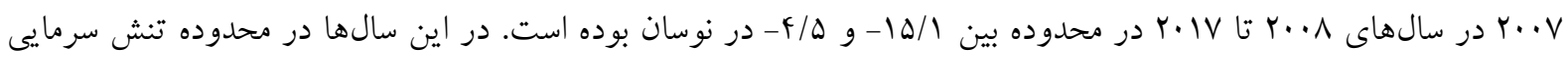
بوده است اما در حال خروج از اين محدوده است و به سمت كرم شدن بيش مىرود. بررسى تغييرات آسايش حرارتى بيرونى در فصول زمستان نشان مىدهد كه اين فصل در طى ده سال (1/1/ PET) در محدوده استرس سرمايى بوده است كه در ماههاى دى و بهمن اين تنش بيشتر ديده مى شود و در ماه اسفند در طى اين مدت تغييرات محدوده سرمايى داشته و به سمت كرم شدن بيش مى مرود. 
1DF

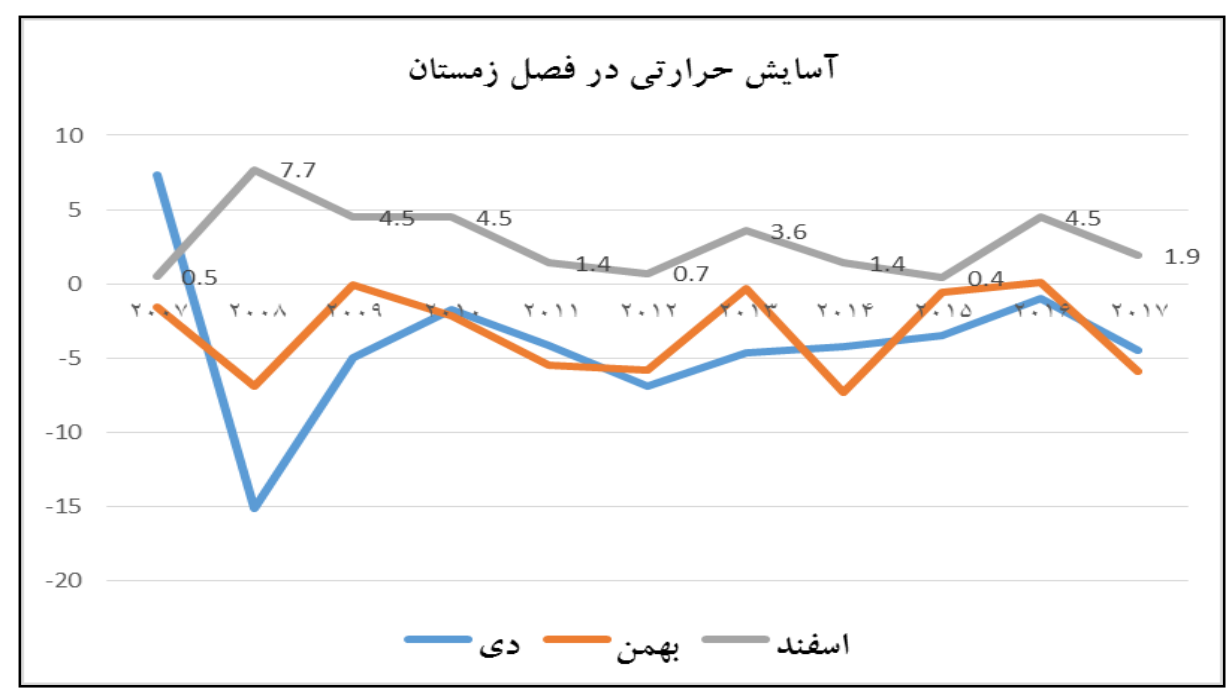

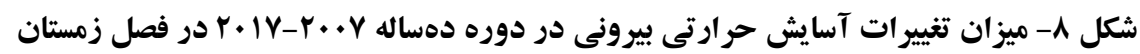

نتيجه گيرى

اين مقاله به دنبال ارزيابى اثرات تغييرات اقليمى بر آسايش حرارتى بيرونى و سلامت انسانها در شهر مشهد، با استفاده از

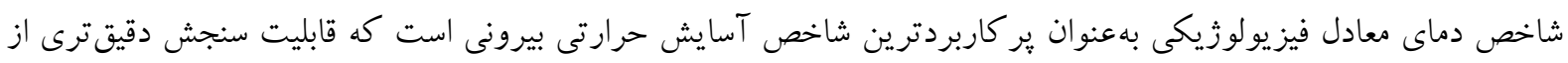

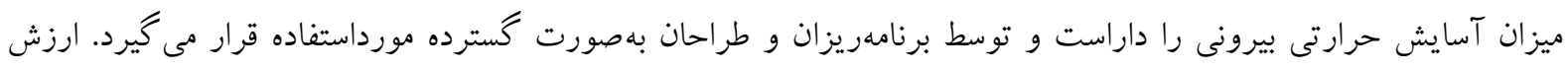

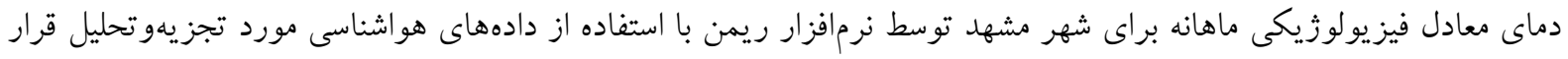

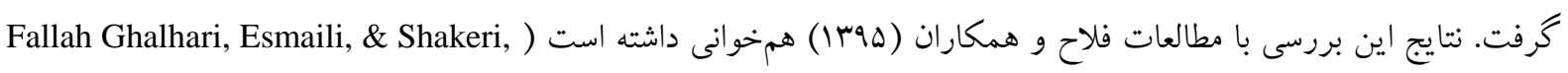

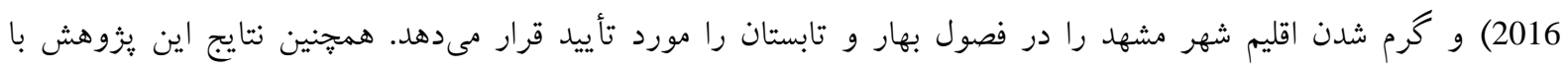

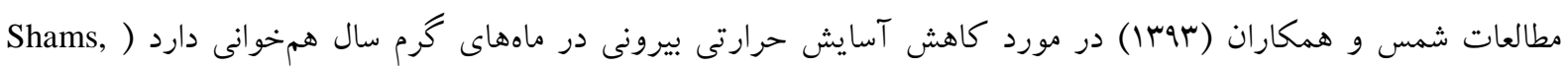

.(Safari Rad, \& Ghasemi, 2014

اين يزوهش نشان مىدهد كه مقدار دماى معادل فيزيولوزيكى با ميزان تغييرات اقليمى نسبت مستقيم دارد و با تشديد اثرات

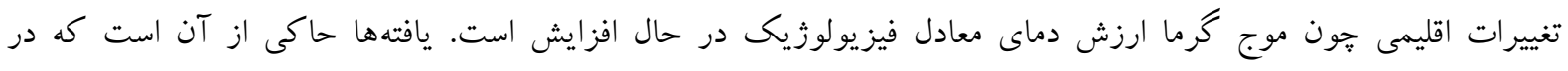

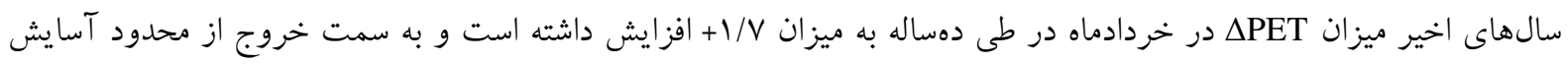

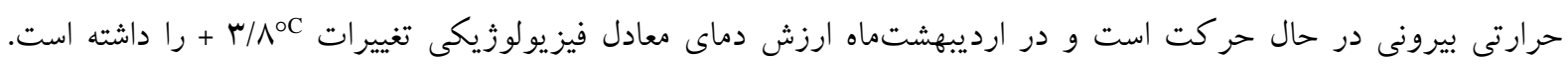

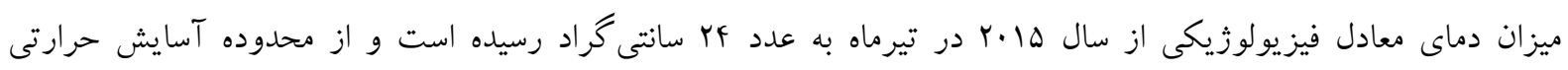

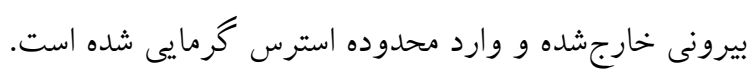

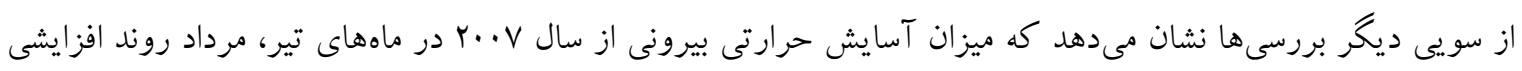

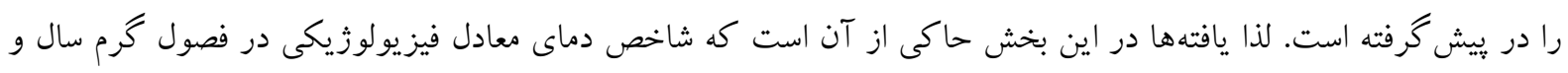

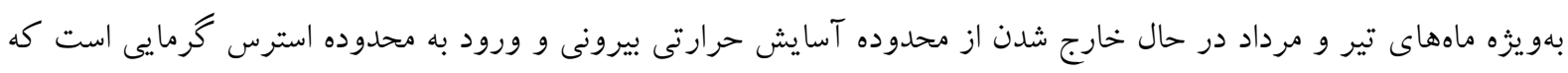

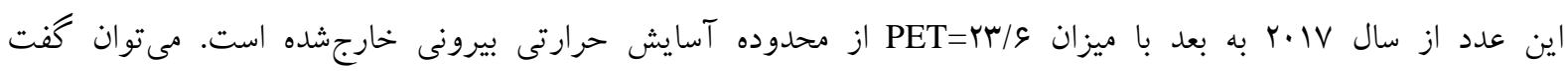

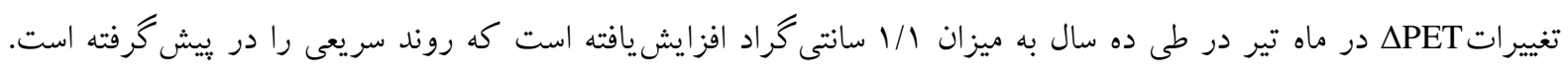

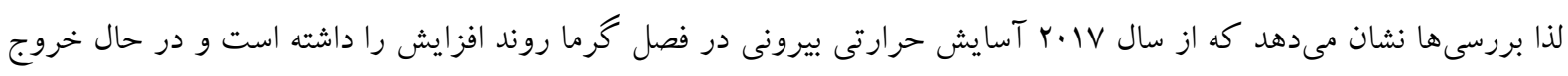


از محدوده آسايش است. بررسىهاى دهاله در فصل پاييز نشان مىدهد كه از سال IV IV در مهرماه دماى معادل فيزيولوزيكى

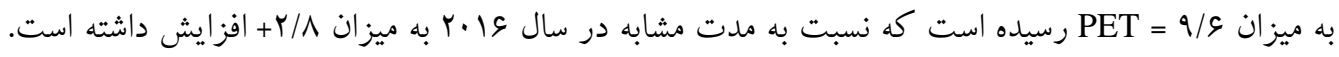

از طرفى ديخر در فصل زمستان علىرغم نوساناتى كه در سالهاى مختلف در ارزش دماى معادل فيزيولوزيكى وجود دارد،

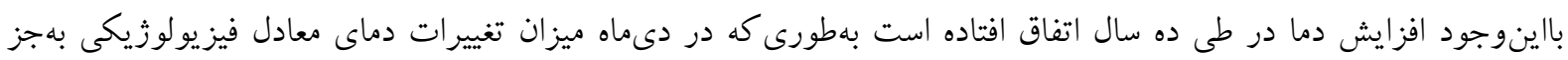

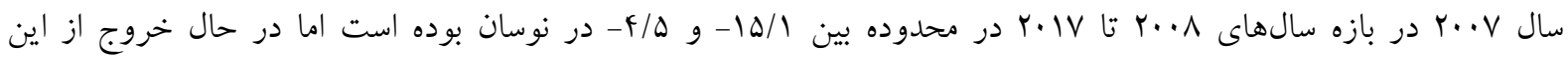

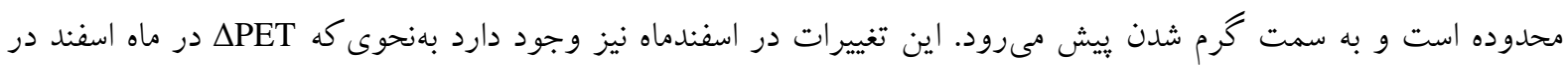

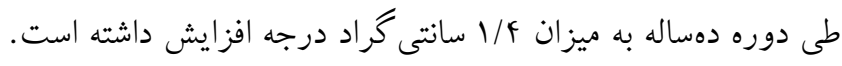

بهعبارتىديخر از ده سال ييش تاكنون ميزان تغييرات DET در زمستان تغييرات جشم گيرى را داشته است. هرجند اين

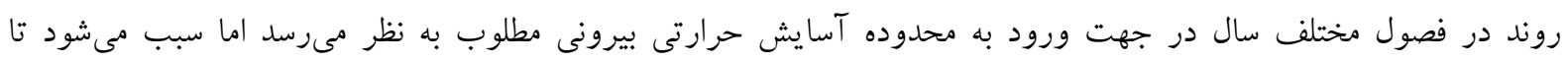

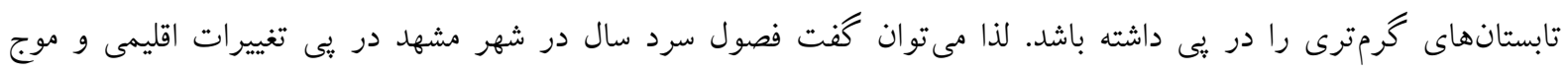

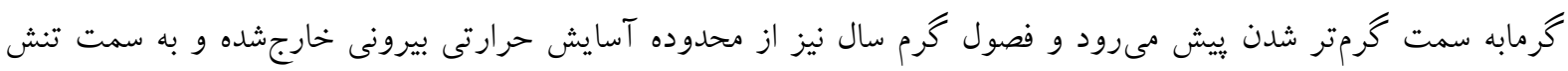

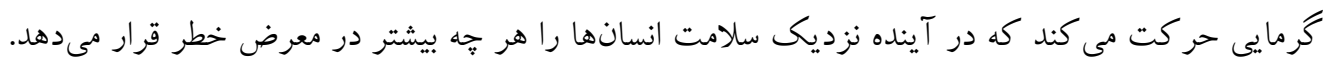

همجنين تغييرات دماى معادل فيزيولوزيكى در ماههاى فروردينماه و ارديبهشت در حال ورود به محدوده آسايش حرارتى

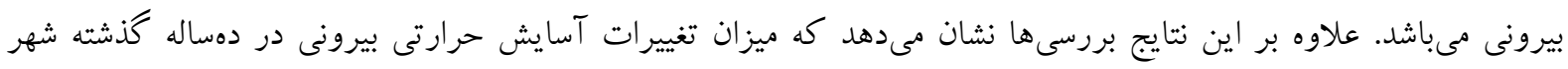

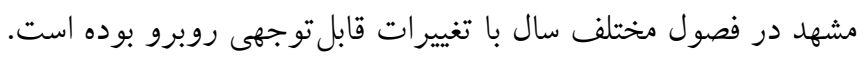

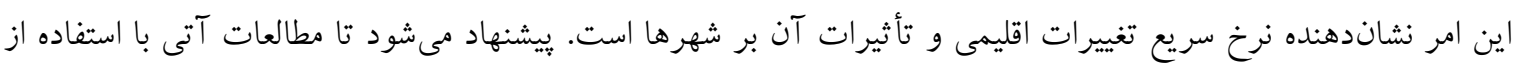

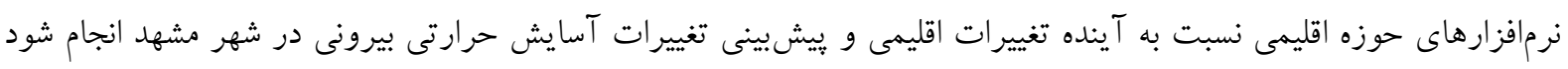

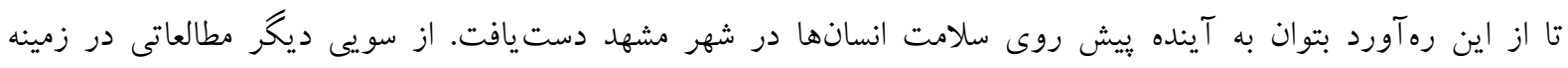

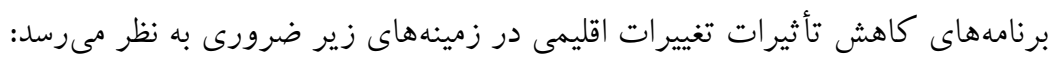

$$
\text { - }
$$

\section{تقدير و تشكر}

بدينوسيله از صندوق حمايت از يزوهشگران و فناوران كشور كه ما را براى انجام اين تحقيق يارى نمودند صميمانه تشكر

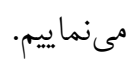

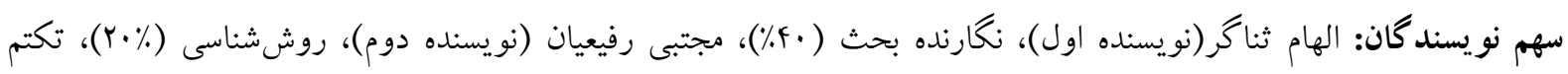

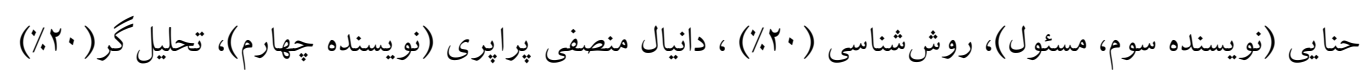




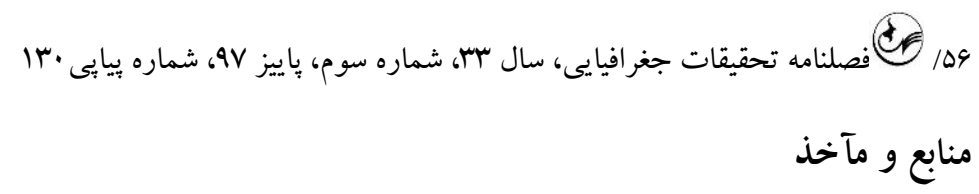

Akbari, H., \& Konopacki, S. (2004). Energy effects of heat-island reduction strategies in Toronto, Canada. Energy, 29(2), 191-210.

Ali-Toudert, F. (2005). Dependence of outdoor thermal comfort on street design in hot and dry climate. (PhD ), Universität Freiburg.

Analitis, A., Katsouyanni, K., Biggeri, A., Baccini, M., Forsberg, B., Bisanti, L., . . Michelozzi, P. (2008). Effects of cold weather on mortality: Results from 15 European cities within the PHEWE project. American Journal of Epidemiology, 168(12), 1397-1408.

ASHRAE. (2009). Fundamentals, American society of heating, refrigerating and air: Conditioning Engineers Pub.

ASHRAE. (2004). Fundamentals, American society of heating, refrigerating and rir: Conditioning Engineers Pub.

Cheung, C. S. C., \& Hart, M. A. (2014). Climate change and thermal comfort in Hong Kong. International Journal of Biometeorology, 58(2), 137-148.

Cimellaro, G. P. (2016). Urban resilience for emergency response and recovery. Switzerland: Springer

Dai, Q. (2014). The impact of urban form on thermal comfort across street zones. (PhD ), The Chinese University of Hong Kong.

Djongyang, N. 1., Tchinda, R., \& Njomo, D. (2010). Thermal comfort: A review paper. Renewable and Sustainable Energy Reviews, 14(9), 2626-2640.

Draper, D. B., \& Richards, P. A. (2009). Dictionary for managing trees in urban environments: Csiro Publishing.

Ebrahimzadeh, I., \& Esmaeil Negad, M. (2017). The future challenge of climatic refugees regional developments dase study: South Khorasan. Geography and Development, 15(48), 1-18. (Persian).

Erell, E., Pearlmutter, D., \& Williamson, T. J. (2010). Urban microclimate: Designing the spaces between buildings. London: Taylor \& Francis Group.

Fallah Ghalhari, G., Esmaili, R., \& Shakeri, F. (2016). Assessing the seasonal variability of thermal stresses during the last half century in some climatic zones of Iran. Iranian Journal of Health and Environment, 9(2), 233-246. (Persian)

Fanger, P. (1970). Thermal comfort: Analysis and applications in environmental engineering. New York: McGraw-Hill pub.

Hajat, S., Armstrong, B., Baccini, M., Biggeri, A., Bisanti, L., Russo, A., . . Kosatsky, T. (2006). Impact of high temperatures on mortality: Is there an added heat wave effect? Epidemiology, 17(5), 632-638.

Hansen, A., Bi, P., Nitschke, M., Ryan, P., Pisaniello, D., \& Tucker, G. (2008). The effect of heat waves on mental health in a temperate Australian city. Environmental Health Persepectives, 116(10), 1369-1375.

Heidari, S., \& Monam, A. (2013). Evaluation of thermal comfort indices in outdoor space,. Journal of Geography and Regional Development, 11(20), 192-216. (Persian)

Hensel, H. (1981). Thermoreception and Temperature Regulation. Monographs of the Physiological Society, 38, 1-321.

Höppe, P. (2002). Different aspects of assessing indoor and outdoor thermal comfort. Energy and Buildings, 34(6), 661-665.

IPCC. (2007). Climate change synthesis report - summary for policymakers: Retrieved from Cambridge University Press.

Johansson, E. (2006). Influence of urban geometry on outdoor thermal comfort in a hot dry climate: A study in Fez, Morocco. Building and Environment, 41(10), 1326-1338.

Karimian, Z. (2013). Optimization of urban green space for the comfort of the warmest period of the year using modeling methods. (PhD ), Ferdosi University of Mashhad, Mashhad. (Persian)

Linares, C., \& D1'az, J. (2008). Impact of high temperatures on hospital admissions: Comparative analysis with previous studies about mortality (Madrid). European Journal of Public Health, 18(3), 317-322.

Matzarakis, A., Mayer, H., \& Rutz, F. (2002). Radiation and thermal comfort. Paper presented at the 6th Hellenic Conference in Meteorology, Climatology and Atmospheric Physics

Matzarakis, A., Rutz, F., \& Mayer, H. (2010). Modelling radiation fluxes in simple and complex environments: basics of the RayMan model. International Journal of Biometeorology, 54(2), 131-139.

Monsefi Parapari, D. (2015). Adaptation to climate change and thermal comfort. (PhD), Dortmund University of Technology.

Morris, J. (2008). History of urban form: Before the industrial revolutions (R. Rezazadeh, Trans.). Tehran: Iran University of Science \& Technology. (Persian)

Oliver, J. E. (2005). Encyclopedia of world climatology. Netherlands: Springer 
Pirard, P., Vandentorren, S., Pascal, M., Laaidi, K., Le Tertre, A., Cassadou, S., \& Ledrans, M. (2005). Summary of the mortality impact assessment of the 2003 heat wave in France. Euro Surveill, 10(7), 153156.

Prasad, N., Ranghieri, F., Shah, F., Trohanis, Z., Kessler, E., \& Sinha, R. (2009). Climate resilient cities: A primer on reducing vulnerabilities to disasters. Washington, DC: World Bank.

Qanbarzadeh, H., \& Behniafar, A. (2007). Fundemental of environmental change. Mashhad: Islamic Azad University Press. (Persian)

Roaf, S., Crichton, D., \& Nicol, F. (2009). Adapting buildings and cities for climate change: A 21st century survival guide. Oxford, United Kingdom: Taylor, Francis Ltd.

Shams, M., Safari Rad, A., \& Ghasemi, A. (2014). Assessing climate conditions of Mashhad city using the quantitative indices of thermal comfort, . Gerographical Journal of Tourism Space, 3(10), 91-104. (Persian)

Szokolay, S. V. (2008). Architectural science the basis of sustainable design. Oxford: Elsevier

Taylor, J., Wilkinson, P., Davies, M., Armstrong, B., Chalabi, Z., Mavrogianni, A., . . Bohnenstengel, S. I. (2015). Mapping the effects of urban heat island, housing, and age on excess heat-related mortality in London. Urban Climate, 14, 517-528.

Wilkinson, P., Landon, M., Armstrong, B., Stevenson, S., \& McKee, M. (2001). Cold comfort: The social and environmental determinants of excess winter death in England. Bristol: The Policy Press.

Yang, L., Qian, F., Song, D.-X., \& Zheng, K.-J. (2016). Research on urban heat-island effect. Procedia Engineering, 169, 11-18.

Yilmaz, S., Akif Irmak, M., \& Matzarakis, A. (2013). The importance of thermal comfort in different elevation for city planning. Global Nest Journal, 15(4), 408-420.

Yow, D. M. (2007). Urban heat Islands: Observations, impacts, and adaptation. Geography Compass, 1(6), 1227-1251.

Zolfaghari, H. (2008). Determination of suitable calendar for tourism in Tabriz with using the thermophysiological indices (PET and PMV). Journal of Geographical Studies, 39(62), 129-141. (Persian) 